UNIVERSIDADE DE SÃO PAULO

FACULDADE DE ECONOMIA, ADMINISTRAÇÃO E CONTABILIDADE

DEPARTAMENTO DE ADMINISTRAÇÃO

PROGRAMA DE PÓS-GRADUAÇÃO EM ADMINISTRAÇÃO

ANA CAROLINA FERREIRA DE SIQUEIRA

Avaliação e aprendizagem: estudo sobre negócios sociais do

Estado de São Paulo

São Paulo 
Prof. Dr. Marco Antonio Zago

Reitor da Universidade de São Paulo

Prof. Dr. Adalberto Américo Fischmann

Diretor da Faculdade de Economia, Administração e Contabilidade

Prof. Dr. Roberto Sbragia

Chefe do Departamento de Administração

Prof. Dr. Moacir de Miranda Oliveira Júnior Coordenador do Programa de Pós-Graduação em Administração 
ANA CAROLINA FERREIRA DE SIQUEIRA

\title{
Avaliação e aprendizagem: estudo sobre negócios sociais do Estado de São Paulo
}

\author{
Dissertação apresentada ao Departamento \\ Administração da Faculdade de Economia, \\ Administração e Contabilidade da \\ Universidade de São Paulo como requisito \\ para a obtenção do título de Mestre em \\ Ciências.
}

Orientador: Prof. Dr. Wilson Aparecido Costa de Amorim

\section{Versão Corrigida}

(versão original disponível na Biblioteca da Faculdade de Economia, Administração e Contabilidade)

São Paulo 


\section{FICHA CATALOGRÁFICA}

\section{Elaborada pela Seção de Processamento Técnico do SBD/FEA/USP}

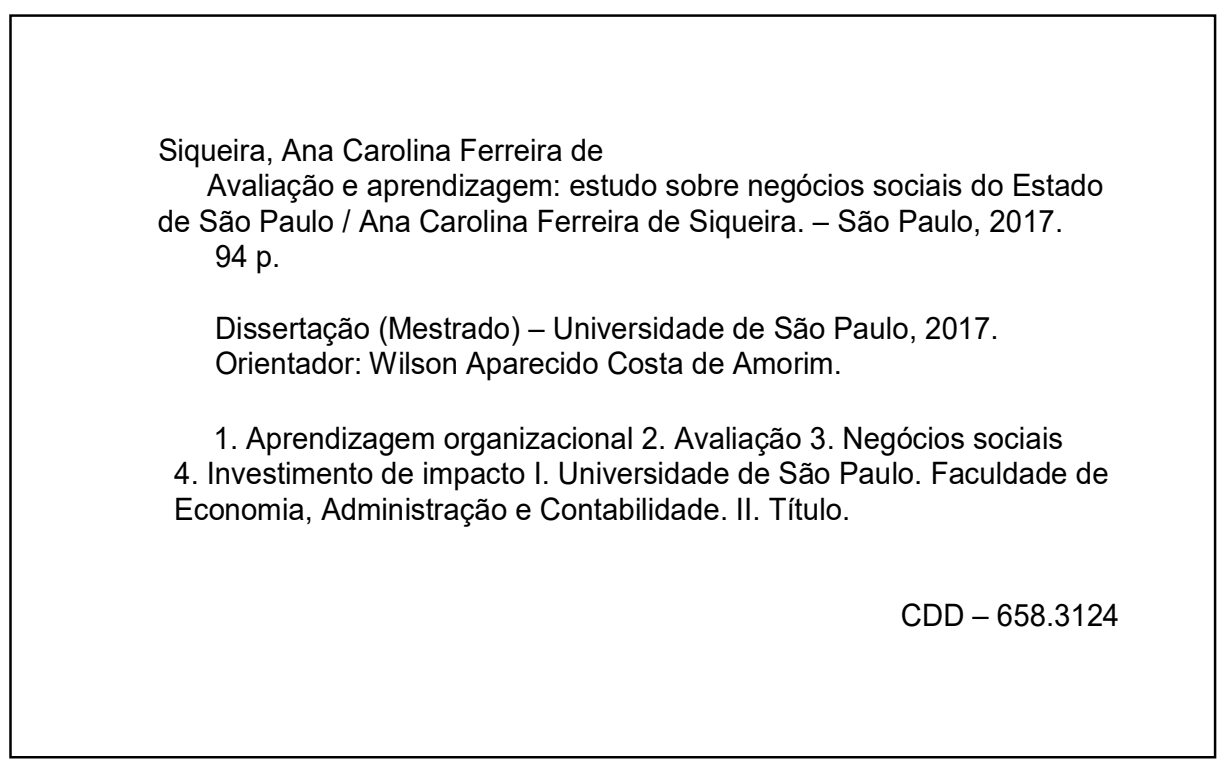




\section{AGRADECIMENTOS}

Agradeço aos meus pais, Daniel e Terezinha, que sofreram com a minha mudança de cidade para fazer esse mestrado, mas que depois me incentivaram quando viram que eu daria conta e minha saúde (mental) não seria prejudicada. Eles me apoiam e confiam todas minhas decisões, até quando não concordam. Muito obrigada!

Agradeço ao meu irmão, Rafael que desde sempre sabia que isso ia dar certo e mesmo assim me impulsionou até quando eu não sabia que precisava. Agradeço ao André que confiou no meu potencial até nas horas que eu não acreditava mais e é o melhor companheiro de casa que eu poderia ter.

Agradeço ao meu orientador, que realmente fez tudo o que se espera desse papel! Ele aceitou o desafio de orientar um assunto que não dominava e me guiou em outros assuntos profissionais além desse trabalho quando pedi ajuda. Aproveito para agradecer às professoras Rosa Maria Fischer e Graziella Comini, que me acolheram no grupo de pesquisa CEATS, do qual eu queria participar desde antes do mestrado.

Agradeço à amiga Nadir, que desde o começo dessa jornada me serviu como inspiração de atuação profissional no campo social. Amiga de qualquer hora, ela recebeu o desafio de ler esse trabalho em 24 horas deu ótimas contribuições! Agradeço também ao Cássio Aoqui que me ajudou com os primeiros contatos com as organizações sociais, o que melhorou muito a minha confiança de que essa pesquisa daria bons frutos. Aproveitando, agradeço a todas as organizações e respondentes que toparam participar dessa pesquisa e se abriram para mim, o trabalho não seria possível sem essa gentileza.

O meu "muito obrigada" também para outras amigas de FEA: Ana Cláudia, Joice, Raissa, Ohana. Vocês tornaram essa fase muito mais agradável e completa para mim! Mesmo! Meus amigos de Brasília, que hoje estão pelo mundo, também fizeram parte dessa jornada. Obrigada, Bárbara, Valéria, Nathalia, Felipe por me ouvirem e rirem de algumas situações que eu me coloquei nesses 2 anos e meio.

Agradeço imensamente à CAPES que por meio da bolsa de mestrado deu as condições para eu viver em São Paulo e levar o mestrado sem precisar de um trabalho de 40 horas por semana. Agradeço muito à USP, que é um dos lugares mais lindos de São Paulo e me deixa feliz só de passear de 8012 (ônibus circular) pela rua do Matão. A universidade me proporcionou fazer uma disciplina no campus leste, que foi uma experiência maravilhosa, comer por 2 reais no "bandeijão", fazer aula de yoga de graça e vários outros privilégios! 
Agradeço à FEA, que sempre me pareceu um lugar muito agradável, desde a entrevista de seleção em que um professor me agradeceu por me candidatar ao programa. Realmente, é uma faculdade de excelência, tenho muito orgulho de fazer parte disso! 


\section{RESUMO}

Os negócios sociais são um fenômeno em expansão no Brasil e no mundo. Este trabalho teve como objetivo geral investigar e analisar se os negócios sociais utilizam práticas de avaliação e se isso gera processos de aprendizagem organizacional, tomando por objeto de estudo organizações que atuam no Estado de São Paulo. Na pesquisa bibliográfica, diversos conceitos de negócios sociais foram identificados, porém, não foram encontradas visões definitivas sobre como avaliar tais organizações. A literatura sobre aprendizagem organizacional também ofereceu insumos à pesquisa. Para alcançar o objetivo proposto, foi usada metodologia de estudo de casos múltiplos, com coleta de dados por meio de entrevistas e análise documental, que se mostrou adequada devido à necessidade de compreensão do contexto das organizações e ao fato de a literatura sobre o tema ainda estar em estágio exploratório. A escolha dos casos se deu a partir de sugestões de fundos de investimento. Em um primeiro momento, os fundos foram contatados e entrevistados, depois indicaram para a pesquisa negócios sociais com os quais se relacionavam, além de duas organizações de avaliação do campo, totalizando quatorze organizações pesquisadas. Os principais resultados deste estudo são: a) caracterização dos negócios sociais que avaliam: destacou-se uma concentração na área de saúde e o alcance ou intenção da sustentabilidade financeira; b) análise das avaliações: elas são principalmente sobre aspectos tradicionais, como operacional e financeiro e acontecem de maneira informal; c) caracterizar se os processos de avaliação geram aprendizagem: sim, os aprendizados acontecem em vários momentos, mas induzidos também por diversos outros fatores além da avaliação, tais como tentativas e erros; d) principais barreiras e dificuldades para a avaliação: dificuldades técnicas nas avaliações sociais e custo em geral. Os negócios sociais pesquisados utilizam práticas de avaliação, mas isso nem sempre gerou aprendizados reconhecidos pelos respondentes. Uma sugestão de pesquisa seria um estudo de caráter qualitativo que investigasse porque essas avaliações não geram todo o aprendizado que poderiam de acordo com a literatura (FRANCO-SANTOS et al., 2007) e o que precisaria mudar para que isso acontecesse. A contribuição teórica dessa pesquisa é uma maior compreensão dos fenômenos de avaliação e aprendizagem nos negócios sociais. A contribuição empírica consiste na indicação de que talvez seja necessário desenvolver o campo em outros aspectos até ele estar maduro o suficiente para executar e tirar benefícios de avaliações. A contribuição de ensino é o questionamento da avaliação como premissa para aprendizagem e melhorias organizacionais.

Palavras-chave: avaliação, aprendizagem organizacional, negócios sociais, investimento de impacto 


\begin{abstract}
Social businesses are a phenomenon in expansion in Brazil and worldwide. This study aims to analyze whether social business working in the state of São Paulo use evaluation practices and, from that, if they experience organizational learning processes. In literature review, different social business concepts have been identified, but there were no definite views on how to evaluate such organizations. The literature on organizational learning and business ecosystem were also reviewed to give input the research. In order to reach the proposed objective, a multiple case study methodology was used, with data collection through interviews and documentary analysis, which was justified by the need to understand the context of organizations and the fact that a literature on the subject is still in an exploratory stage. The cases choice was based on investment fund suggestions. Initially, the funds were contacted and interviewed, then they indicated social business they invested on to be researched, in addition to two field evaluation organizations, totaling fourteen researched organizations. The main results of this study were: a) characterization of the social businesses that evaluate: a concentration in the health area and the reach of the intention of the financial sustainability; b) Analysis of evaluations: they are mainly informal about tradition aspects such as finance and operations; c) To identify if the processes of evaluation generate learning: yes, the learnings take place at several moments, but also induced by several other factors besides the evaluation, such as trial and error; d) Main barriers and difficulties for evaluation: technical difficulties of social evaluations and cost in general. The businesses researched evaluate their performance, but it did not always generated learning recognized by respondents. A research suggestion would be qualitative investigation to discover why assessments did not lead to learning in a better way as literature suggests (FRANCOSANTOS et al., 2007) and what would need to change for this to happen. The theoretical contribution of the research is an early understanding of the phenomena of evaluation and learning in business. The empirical contribution is the indication that it may be necessary to develop the social business ecosystem in other aspects until it is mature enough to perform and benefit from evaluation. The contribution for teaching is questioning evaluation as a premise for learning organizational and improvements.
\end{abstract}

Keyword: Evaluation, organizational learning, social business, impact investment 


\section{LISTA DE FIGURAS}

Figura 1- Nuvem de palavras mais ditas nas entrevistas ............................................ 75 


\section{LISTA DE QUADROS}

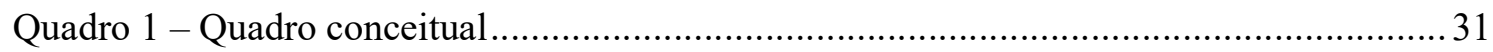

Quadro 2 - Relação entre objetivos, questões de roteiro e literatura .................................... 37

Quadro 3 - Principais considerações das organizações contatadas....................................... 41

Quadro 4 - Relação de investidores e negócios investidos................................................. 43

Quadro 5- Objetivos, categorias e resultados encontrados............................................ 70

Quadro 6- Número de referências por categoria................................................................... 76

Quadro 7- Relação entre lições aprendidas e organizações................................................77 


\section{SUMÁRIO}

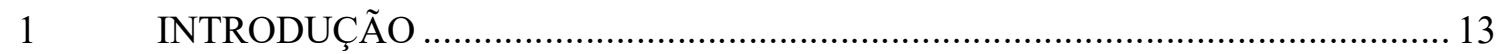

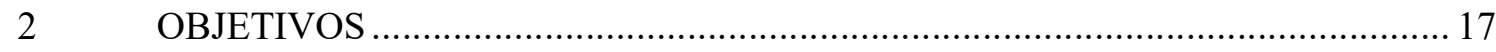

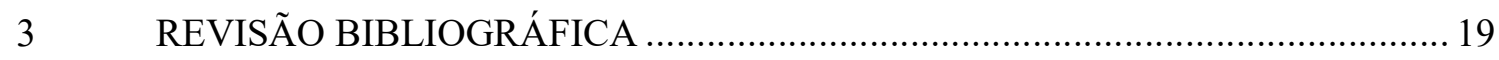

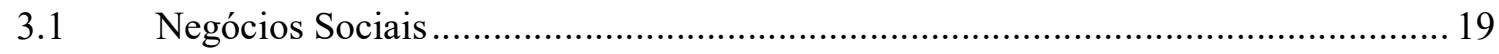

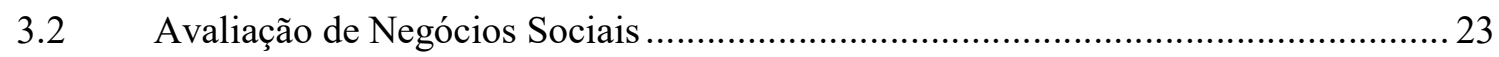

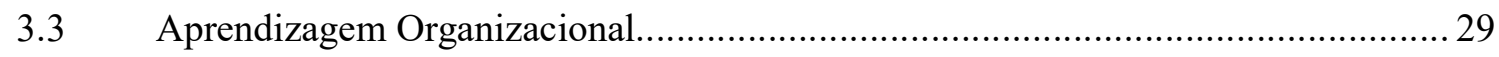

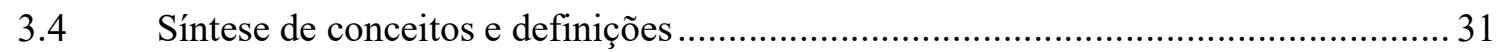

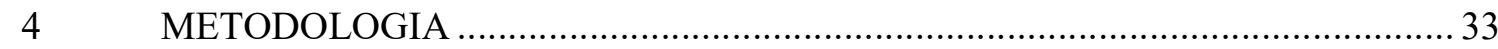

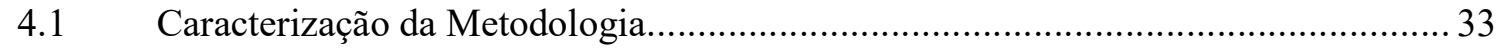

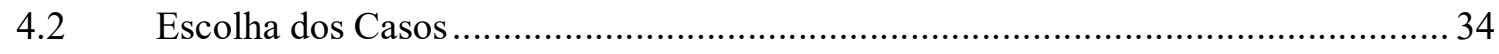

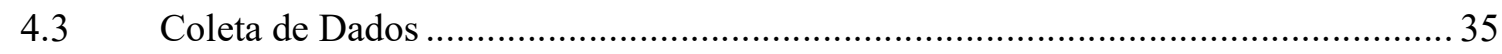

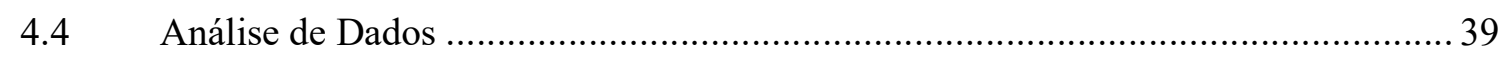

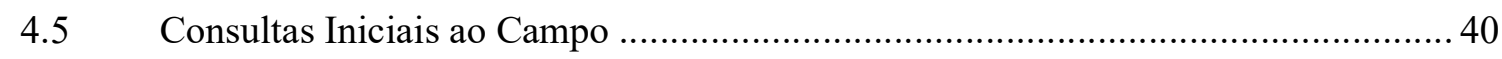

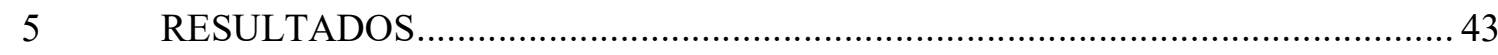

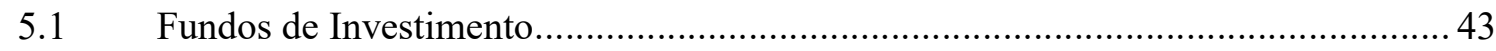

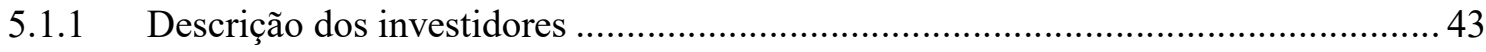

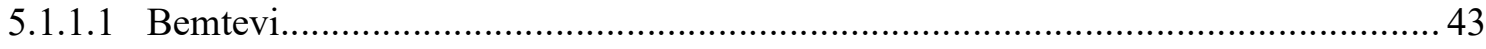

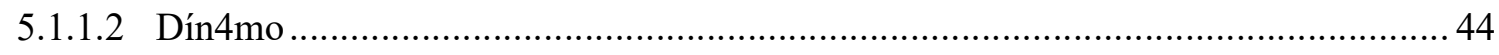

5.1.1.3 GAG

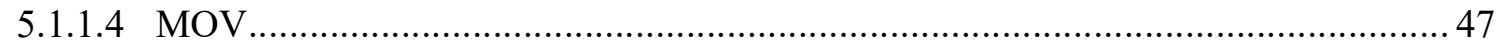

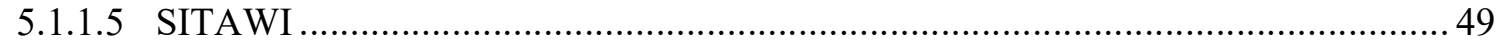

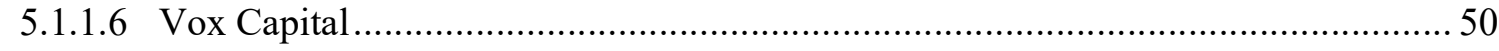

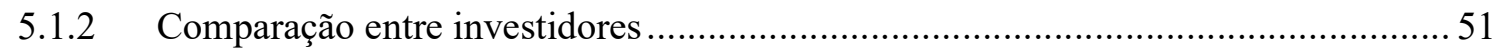

5.2.1 Descrição dos negócios sociais ....................................................................... 54

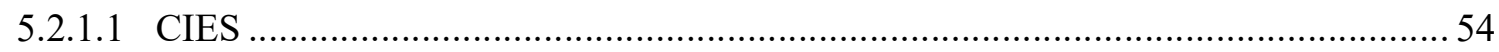




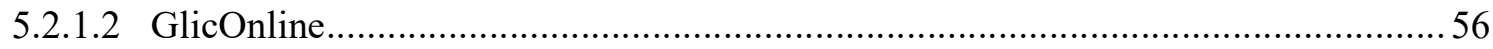

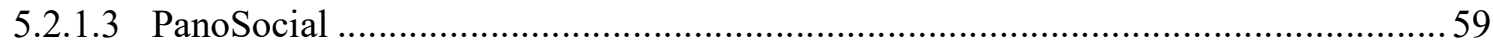

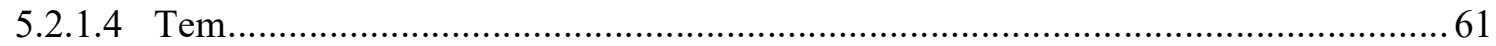

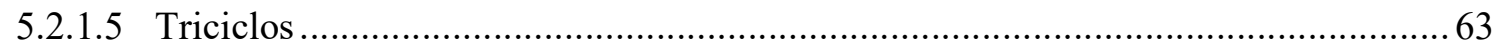

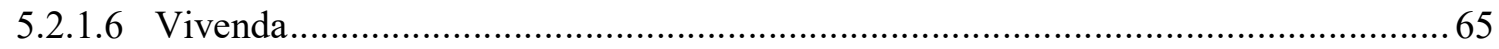

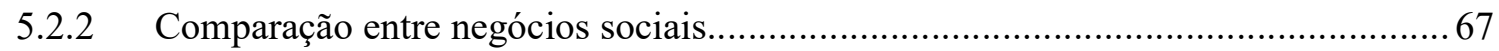

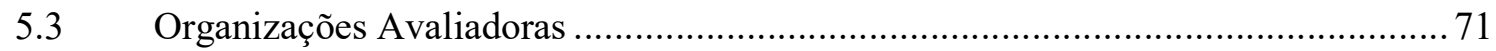

5.3.1 Descrição das Organizações ....................................................................... 71

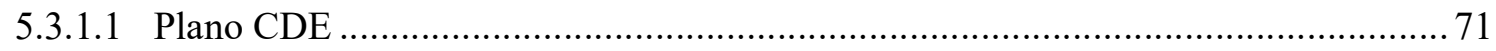

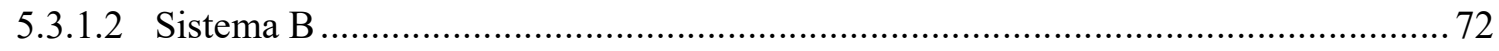

5.3.2 Comparação das Organizações Avaliadoras ..................................................... 73

6 ANÁLISE COMPARATIVA ENTRE TODAS AS ORGANIZAÇÕES POR

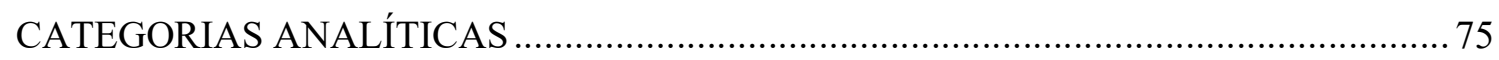

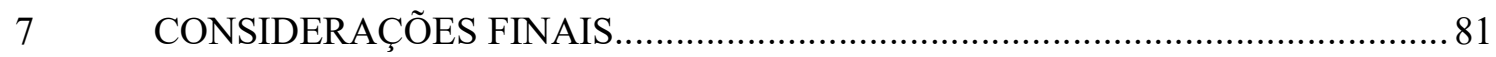

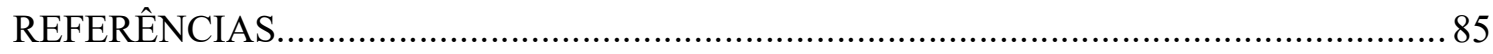

APÊNDICE 1 - ROTEIRO DE ENTREVISTAS PRELIMINARES (ACELERADORAS E

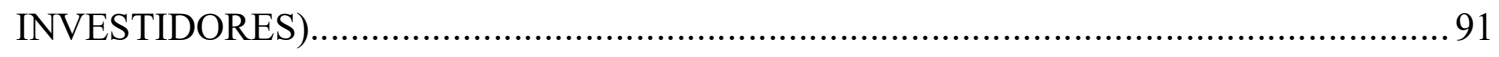

APÊNDICE 2 - ROTEIRO DE ANÁLISE DOCUMENTAL E ENTREVISTAS COM

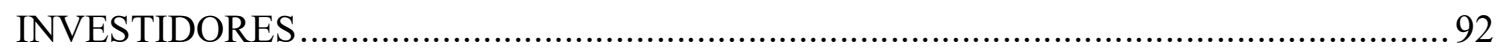

APÊNDICE 3 - ROTEIRO DE ANÁLISE DOCUMENTAL ENTREVISTAS COM

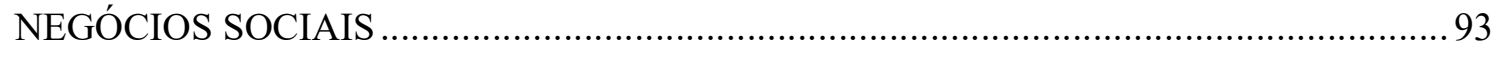




\section{INTRODUÇÃO}

A presente pesquisa repousa na observação de que "apesar da amplitude dos problemas sociais e da crescente preocupação com as falhas de mercado que geram desigualdades" (BIGNETTI, 2011, p. 3), os estudos sobre avaliação de projetos e negócios sociais ainda não representam parcela significativa das pesquisas acadêmicas em Administração. Os estudos que relacionam a avaliação a uma de suas possíveis consequências, a aprendizagem organizacional, são ainda menos frequentes.

Negócios sociais são entendidos neste estudo como “organizações que têm o objetivo de resolver problemas sociais de forma eficiente e com sustentabilidade financeira por meio de mecanismo de mercado" (FISCHER; COMINI, 2012, p. 367). E a aprendizagem organizacional como o "processo de construção social que responde a eventos internos e externos na organização criando novas interpretações da realidade que são armazenadas na memória organizacional quando devidamente institucionalizadas." (AMORIM; FISCHER, 2009, p.121 a partir de PRANGE, 2001).

Os negócios sociais têm as pessoas de baixa renda como público-alvo. Prahalad e Hart (2002) chamavam atenção para o tamanho do mercado de consumo que as classes sociais mais baixas, "base da pirâmide", podem representar mesmo tendo em vista uma baixa renda individual. Este segmento, apesar de seu baixo poder aquisitivo, em seu conjunto, tem grande poder de consumo se for considerado o grande número de pessoas que possui pouca renda. Além disso, conforme Keynes, a propensão marginal a consumir é maior entre as pessoas de menor renda (MANKIW, 2010). Assim, as pessoas com menos renda tendem a dirigi-la proporcionalmente mais ao consumo do que à poupança quando comparadas com as pessoas de maior renda (MANKIW, 2010).

Os negócios sociais mostram-se cada vez mais presentes em diversos países, como no Brasil, especialmente na cidade de São Paulo. O instituto de pesquisa Plano CDE em um levantamento feito em 2011 encontrou 50 negócios inclusivos ou sociais, sendo 42\% deles no Estado de São Paulo. Essa mesma pesquisa também identificou um ecossistema formado por 40 desenvolvedores (como incubadoras e consultorias) e 14 investidores. O mesmo levantamento apontou, ainda, que metade dos negócios pesquisam dados sobre seu impacto social (AGUIAR; NAIGEBORIN, 2013). O levantamento da Pipe Social feito em 2017 contou com 579 negócios sociais, sendo 43\% deles no Estado de São Paulo. 79\% do total de negócios captam investimento externo e apenas $8 \%$ avaliam formalmente o impacto social (PIPE SOCIAL, 2017). 
A diferença entre os dois levantamentos indica uma evolução do setor, em que mais negócios surgiram. É possível que a diminuição do percentual de negócios que avaliam seu impacto deva-se a um posicionamento mais crítico do setor que passou a enxergar avaliação de impacto como algo mais robusto que exige grande rigor metodológico. Ou também ao fato de que como há mais negócios, alguns sejam menos planejamos do que deveriam.

$\mathrm{O}$ alcance de alguns negócios sociais brasileiros surpreende em sua abrangência. Em dois exemplos, o Projeto CIES (Centro de Integração de Educação e Saúde) - voltado para a prestação de serviços de saúde, tais como consultas e exames de simples e média complexidade - já atendeu 250 mil pessoas em seis estados (PROJETO CIES, 2015) e a Konkero - cujo foco de atuação é a orientação financeira - já auxiliou mais de 2 milhões de pessoas por meio de seu site (KONKERO, 2015).

Apesar da relevância crescente dos negócios sociais em termos empíricos, o seu campo de estudos ainda está em construção (ROSOLEN; TISCOSKI; COMINI, 2014). Uma das lacunas de pesquisa que permanece é a ausência de uma análise sistemática e ampla voltada para os negócios sociais, o que tende a prejudicar a sua atuação, pois "qualquer organização precisa saber se seus objetivos estão sendo alcançados” (OLIVEIRA FILHO; KIYAMA; COMINI, 2013).

Neste estudo, as avaliações abrangiam os aspectos operacionais, financeiros e sociais. Oliveira Filho et al.(2013) mostram que há duas questões principais que dificultam a avaliação de negócios sociais. A primeira diz respeito à inadequação das medidas tradicionais de gestão à mensuração deste tipo de negócio. E a segunda à grande diversidade de interesses dos stakeholders dos negócios sociais que precisam ser contemplados na avaliação. $\mathrm{O}$ stakeholder pode ser "qualquer grupo ou indivíduo que pode afetar ou ser afetado pelo atingimento dos objetivos organizacionais" (FREEMAN, 1984, p. 46). Os principais stakeholders interessados na avaliação dos negócios sociais são o público beneficiado, os gestores e os investidores (OLIVEIRA FILHO; KIYAMA; COMINI, 2013). Esta pesquisa tem seu foco nestes dois últimos stakeholders. O público beneficiado não será tratado aqui, pois nesse estudo a perspectiva é a da organização e seus gestores.

Tendo por base esse contexto, o trabalho teve como pergunta de pesquisa: os negócios sociais utilizam práticas de avaliação? Isso gera processos de aprendizagem organizacional?

Além disso, houve interesse em evidenciar quais são os motivos e finalidades da avaliação e a quem ela se destina.

Para responder a essas questões, foram contatados investidores que indicaram negócios sociais com os quais se relacionam e avaliam. Essa ideia partiu da suposição de que 
um dos maiores fatores que influenciavam a avaliação era a demanda dos investidores sobre isso.

Apesar das barreiras existentes nos processos de avaliação, ela pode gerar diversos benefícios, tais como a aprendizagem (FRANCO-SANTOS, KENNERLEY, MICHELI, MARTINEZ, MASON, MARR, GRAY, NEELY, 2007). No cenário atual de competitividade, inovação e globalização, "detectar os melhores caminhos para o desenvolvimento de processos de disseminação e criação de conhecimento e aprendizagem encontra-se entre as prioridades das organizações” (AMORIM; FISCHER, 2013, p. 330). 


\section{OBJETIVOS}

O objetivo geral desta pesquisa é analisar se os negócios sociais utilizam práticas de avaliação e se isso gera processos de aprendizagem organizacional, tomando por objeto organizações que atuam no Estado de São Paulo.

Objetivos específicos:

a) Caracterizar o negócio social que faz avaliação;

b) Caracterizar e analisar processos avaliação nos negócios sociais;

c) Identificar e caracterizar se os processos de avaliação geram aprendizagem organizacional na forma de lições aprendidas;

d) Identificar e analisar se existem barreiras ou dificuldades para os processos de avaliação.

Há algumas contribuições acadêmicas e práticas principais que se pretendia alcançar com esse trabalho. Uma contribuição acadêmica refere-se à constatação de uma relação entre a avaliação de desempenho e a aprendizagem organizacional em negócios sociais. Outra se refere à maior compreensão do fenômeno da aprendizagem organizacional, ainda pouco claro nos estudos em administração, especialmente no que ocorre em organizações sociais.

$\mathrm{Na}$ literatura voltada para o campo prático e em encontros específicos de interesses do setor, tais como fóruns, um dos principais desafios identificados é encontrar uma forma adequada de avaliar o desempenho dos negócios sociais. Uma contribuição prática do trabalho é a expectativa de colaborar para o alcance desse desafio. 


\section{REVISÃO BIBLIOGRÁFICA}

Nesta seção são apresentados os principais conceitos que orientam o trabalho: negócios sociais e seu ecossistema, avaliação de negócios sociais e aprendizagem organizacional. Ao final serão indicados sinteticamente os conceitos a serem utilizados na elaboração dos instrumentos de pesquisa e na análise dos dados resultantes da coleta de dados.

\subsection{Negócios Sociais}

Por se tratar de um fenômeno recente, há diferentes nomenclaturas para definir negócios sociais. A OECD (2006) define empresas sociais como organizações que buscam objetivos econômicos e sociais com espírito empreendedor e que apresentam propósitos para além da maximização de lucro. Yunus e Weber (2007) mostram que negócios sociais diferem de filantropia por uma principal razão: são autossustentáveis financeiramente. Uma vez que eles são construídos, continuam a crescer por si mesmos sem precisar de doações. Yunus, Moingeon e Lehmann-Ortega (2010) especificam que os negócios sociais costumam procurar investimento externo apenas no começo do desenvolvimento de sua atuação. Uma pesquisa realizada no Brasil aponta que 79\% dos respondentes captam investimento (PIPE, 2017). É possível que esse achado se deva ao momento inicial em que o ecossistema e parte dos negócios sociais se encontrem, já que a mesma pesquisa encontrou $40 \%$ de negócios com menos de 3 anos.

Fischer (2014, p. 207) reforça que "os negócios sociais devem gozar de autonomia e sustentabilidade financeira. [...] Distinguem-se, portanto, das organizações filantrópicas, [...] mesmo quando sua atuação guarda forte identidade com uma causa social ou ambiental". As práticas dos negócios sociais também se distinguem das práticas de responsabilidade social das organizações privadas tradicionais. Nas primeiras, as questões sociais são tratadas como o núcleo de atuação e nas segundas, apenas como assuntos periféricos para compensar as externalidades negativas causadas pela organização (PORTER; KRAMER, 2006).

A Acumen é uma organização que levanta doações de recursos financeiros para investir em outras organizações, líderes e ideias de combate à pobreza (ACUMEN, 2017). Para essa organização, os negócios sociais idealmente se caracterizam por uma atuação com grande abrangência ou escala (a quantidade de pessoas que conseguem alcançar os benefícios de um bem ou serviço), profundidade (melhorias causadas no bem-estar de uma família) e foco nos pobres (a proporção de clientes que é de baixa renda). Um negócio que tenha esses 
três indicadores altos seria escalável, significativo e com impacto nas pessoas de baixa renda (ACUMEN, 2014).

Yunus e Weber (2007) apontam dois tipos de negócios sociais. O primeiro tipo é o que pretende resolver problemas sociais com sustentabilidade financeira por meio de mecanismos de mercado. O segundo tipo é composto por empresas ou cooperativas cujo produto ou serviço não necessariamente tem como público-alvo as pessoas de baixa renda. Entretanto, quando tais negócios geram ocupação para pessoas de baixa renda, encontra-se aí a possibilidade de melhoria da qualidade de vida.

Para Yunus, Moingeon e Lehmann-Ortega (2010) o segundo tipo é possível porque empreendedorismo não é uma qualidade rara entre pessoas de baixa renda. Yunus descobriu isso quando começou a emprestar dinheiro às pessoas pobres nos anos 70 , por meio do Grameen Bank, um dos primeiros negócios sociais a surgir no mundo. Karnani (2007), por outro lado, afirma que a maior parte desses empreendedores não é capacitada, uma condição necessária para o empreendedorismo, não fez essa escolha por opção e preferiria ter um trabalho tradicional, com salário fixo.

Em relatório elaborado pelo banco J.P.Morgan (2010), são apresentadas também duas formas pelas quais os negócios sociais podem atuar, muito semelhantes às descritas por Yunus e Weber (2007). Uma delas consiste na expansão do acesso a serviços básicos para populações de baixa renda (como habitação, educação, serviços financeiros, saúde e outros) e outra por meio de um processo produtivo que inclua uma população marginalizada na cadeia de produção (como criação de emprego e compra de produtores locais).

Os negócios sociais também recebem o nome de negócios inclusivos ou empresas sociais. Cominiet al. (2012) mostram que os diferentes nomes resultam da influência de sua origem geográfica e apresentam as distinções que existem entre os termos da Europa, Estados Unidos e países em desenvolvimento. No Brasil, o termo mais utilizado é "negócios sociais". A Social Enterprise Knowledge Network (SEKN), uma rede formada pelas principais escolas de administração da América Latina os define como "as organizações que causam mudança social por meio de mecanismos de mercado" (COMINI; BARKI; AGUIAR, 2012, p. 390).

Yunus et al.(2010, p. 309) especificam que negócios sociais são "empresas autossustentáveis que vendem produtos ou serviços para pagar o investimento de seus sócios, mas cujo propósito principal é melhorar a vida dos pobres". Ressalta-se que não foram pesquisadas organizações do tipo negócios para a base da pirâmide, ou seja, negócios tradicionais que enxergam na base de pirâmide uma simples oportunidade de mercado 
(PRAHALAD; HART, 2002) sem se preocupar com a elevação da qualidade de vida das pessoas de baixa renda.

O SEBRAE é "um agente de capacitação e de promoção do desenvolvimento, criado para dar apoio aos pequenos negócios de todo o país” (SEBRAE, 2015a), ele prioriza “esforços para estimular, atender e apoiar aqueles que dentre o seu público-alvo original pequenos negócios buscam agregar uma nova dimensão ao ambiente empresarial e despertar uma nova consciência social, respondendo a problemas concretos do cenário econômico e social do país" (SEBRAE, 2015b) por meio de apoio aos negócios sociais. Isso mostra a relevância que os negócios sociais ganham no país.

O SEBRAE (2015c) identifica:

[...] negócios sociais como iniciativas financeiramente sustentáveis, geridas por pequenos negócios, com viés econômico e caráter social e/ou ambiental, que contribuam para transformar a realidade de populações menos favorecidas e fomentem o desenvolvimento da economia nacional.

Vale notar que nem sempre os negócios sociais são pequenos, tanto pela ótica de faturamento quanto pelo número de empregados, porém o SEBRAE ressalta esse porte em sua definição porque é o único com o qual trabalha. O SEBRAE também mostra quais negócios não são sociais: empresas de grande porte que apenas viabilizam o acesso a bens para uma comunidade de baixa renda sem foco na melhoria da qualidade de vida dessa população; organizações que usam mão de obra de baixa renda sem se atentar para a precarização das relações de trabalho; ONGs que geram renda para se sustentar, mas não consideram essa atividade uma estratégia para gerar impacto social.

Uma característica associada aos negócios sociais é que o mecanismo de mercado utilizado por eles, seja de pequeno, médio ou grande porte, conta com oferta e consumo em escala. Como os clientes não possuem muito poder aquisitivo é preciso que o preço final seja baixo para ser acessível. A sustentabilidade financeira provém então da grande quantidade de bens ou serviços vendidos com uma margem de lucro pequena (TASHMAN; MARANO, 2010).

Karnani (2007) defende que a visão dos pobres como consumidores pode trazer grandes prejuízos tanto ambientais quanto sociais. Uma estratégia comum para tornar os preços mais acessíveis é a divisão do pagamento em parcelas mensais, o que pode gerar dívidas, dado que muitas vezes a base da pirâmide tem uma renda pouco estável ao longo do tempo. O mais correto seria encorajá-los a guardarem dinheiro para comprar à vista. Um dos maiores argumentos do autor é que a base da pirâmide deveria ser vista como produtora de bens e serviços e não consumidora. 
Agnihotri (2013) mostra casos em que os pobres participaram de negócios atuando na cadeia de suprimentos, como sócios ou donos e como funcionários. $\mathrm{O}$ autor recomenda que para bens ou serviços hedonistas, tais como turismo, seria melhor os pobres atuarem na cadeia de produção do que como consumidores. Para os bens ou serviços que apresentam um valor mais utilitarista, tais como saúde, educação e nutrição, uma boa estratégia dos negócios sociais é disponibilizá-los de forma acessível, a um preço menor e com as adaptações necessárias, tais como utilizar pessoas da própria comunidade, que também são de baixa renda na distribuição. O benefício para as pessoas de baixa renda pode ser especialmente importante quando meios de produção, tais como máquinas de costura ou câmeras para serviços de fotógrafos tornam-se acessíveis e criam a possibilidade de geração de renda para essa população.

Uma característica relacionada ao ambiente de atuação dos negócios sociais é que há diversas organizações que os apoiam para o alcance de escala e longevidade, tais como investidores, aceleradoras, consultorias, entre outros. A esse grupo de organizações, convencionou-se chamar de ecossistema. Uma organização pode ser vista não como um membro de um único setor, mas como parte de um ecossistema de negócios (MOORE, 1993).

"Um ecossistema de negócios, assim com um biológico, evolui de uma coletividade aleatória de elementos para uma comunidade mais estruturada" (MOORE, 1993, p. 76) que funciona, de acordo com o autor, por meio de cooperação e competição. Moore (1993) reconhece que a metáfora do ecossistema apresenta limites para entender o ambiente empresarial, pois ele é social e as decisões dependem do que os gestores pensam e de que informações eles têm acesso, mesmo assim, sinaliza que o termo capta as principais características do fenômeno social. Apesar dessas limitações, o termo é amplamente utilizado em pesquisas acadêmicas sobre negócios sociais (ARIZONA-MONTES; MUNIZ, 2013; SILVA, 2013; BARKI et al., 2015) por esse motivo, também será adotado nesta.

Arizona-Montes e Muniz (2013) sistematizaram o ecossistema de negócios sociais separando as atividades das organizações apoiadoras em: financiamento, rede de contatos, treinamento aconselhamento e infraestrutura. No que tange ao treinamento, que pode ser identificado como um incentivo à aprendizagem, eles chamam atenção para o fato de que os formatos presenciais, muitas vezes são inacessíveis para pequenos empreendedores sociais devido ao custo monetário e de tempo. Pensando nisso, diversas instituições desenvolveram cursos mais baratos e à distância. Os autores defendem que o ideal seria um modelo que mesclasse as duas metodologias. 
Do apresentado, foram tiradas as referências para identificar quais organizações são negócios sociais e serão usadas na pesquisa. Foi importante ter claro quais são as diferenças entre o conceito escolhido e outros próximos como organizações sociais tradicionais e responsabilidade social. Foi necessário para a realização do estudo também identificar quais são algumas de suas implicações, tal como de que forma as pessoas de baixa renda podem ser beneficiadas. Ainda, foi fundamental compreender os conceitos das principais organizações do ecossistema com as quais se relacionam para caracterizar melhor o ambiente em que estão inseridas e localizar as organizações que fazem parte dele.

\subsection{Avaliação de Negócios Sociais}

A avaliação de negócios sociais foi tratada nessa pesquisa com foco em indicadores de desempenho, porém, de forma mais abrangente do que a avaliação de desempenho tradicional. Neste estudo, as avaliações abrangiam os aspectos operacionais, financeiros e sociais.

Para acompanhar o andamento da gestão em seus sucessos ou problemas, tanto os negócios sociais quanto as organizações que os apoiam precisam medir seus resultados alcançados. Porém, essa não é uma tarefa fácil (COMINI; BARKI; AGUIAR, 2012). Historicamente, medidas de gestão eram usadas para controlar o comportamento dos funcionários, como na Administração Científica. Muitas organizações ainda não se livraram desse pensamento e usam sistemas de mensuração para reforçar ou punir. Um uso melhor dos sistemas de mensuração seria a entrega de informações para o processo decisório e proporcionar o aprendizado e a contribuição dos funcionários para a evolução do desempenho empresarial (MARR, 2006).

Marr (2006) prefere usar o termo "indicadores" a "mensuração", pois o primeiro pretende mostrar apenas uma tendência, enquanto mensuração pretende medir algo mais específico. Em ambientes sociais, como organizações, não há uma verdade única e absoluta a ser encontrada e sim tendências que devem ser interpretadas. Se não houver mudança ou reforço de comportamento, que caracterizam a aprendizagem posterior à análise e interpretação das tendências, a mensuração tem pouco valor.

Meyer (2007) aponta que apesar de indicadores de gestão serem bastantes presentes nas organizações, há uma grande insatisfação com eles. Os indicadores ideais seriam poucos, os que medem dados não financeiros iriam predizer os financeiros, os mesmos indicadores seriam válidos para a empresa como um todo, as medidas seriam estáveis ao longo do tempo (de forma que seria possível fazer e acompanhar objetivos de longo prazo) e as pessoas seriam 
recompensadas com base neles. Não há nenhum sistema de medida que concentre todos esses benefícios.

Um dos maiores problemas dos sistemas de indicadores que as empresas costumam usar é que eles são adotados com base em benchmarking e não há uma reflexão sobre o que realmente importa ser medido, o que agrega valor ao cliente, o que deve ser priorizado no desempenho (MEYER, 2007). Esse impasse não se mostrou muito presente nos negócios sociais pesquisados.

Outro problema comum nos indicadores tradicionais é a dificuldade em medir aspectos intangíveis, que foi tratada pela criação do Balanced Score Card (BSC) (KAPLAN, NORTON, 2001). Este esquema de acompanhamento de resultados, chamado de "mapa estratégico" considera quatro perspectivas: finanças, consumidor, processos internos do negócio e aprendizagem e crescimento. A perspectiva aprendizagem e crescimento é a base de todo o mapa estratégico, a partir dela os gestores podem definir as habilidades necessárias aos funcionários para apoiarem a organização a alcançar seus objetivos estratégicos.

O Balanced Score Card pode ser usado em organizações sociais com algumas adaptações (KAPLAN; NORTON, 2001). Estes autores chamam atenção para o fato de que os relatórios estratégicos de organizações sociais, em muitos casos, são focados nos programas e projetos em execução e não nos objetivos destas organizações. Para que o BSC realmente funcione de forma estratégica é preciso uma liderança e visão que procurem não apenas melhorar os processos, mas identificar quais são as atividades e processos mais importantes para alcançar a missão pretendida. É recomendado colocar a missão da organização no topo do mapa estratégico e não a perspectiva financeira como o BSC tradicional faz, dado que o objetivo principal das organizações não é lucro (KAPLAN; NORTON, 2001).

Marr (2006) aponta alguns aspectos importantes na criação de um indicador especialmente para organizações tradicionais. Além dos aspectos mais conhecidos tradicionalmente, o autor chama atenção para alguns deles: propósito, é fundamental conhecer a utilização de uma medida, algumas das funções podem ser recompensar funcionários e a apresentação para acionistas; data de revisão, é fundamental revisar a necessidade de indicadores após um período, algo que foi prioritário em um momento pode não ser mais; estimativa de custos, há um custo envolvido nas atividades de um sistema de indicadores, especialmente nos mais relevantes, que tendem a ser mais difíceis de acessar.

Nos levantamentos empíricos preliminares desta pesquisa, os gestores de algumas organizações apontaram em entrevistas que uma das grandes barreiras para os negócios sociais avaliarem seu desempenho é o custo atrelado a isso. Como os negócios costumam ter 
equipes bem enxutas, não é possível designar um funcionário apenas para essa atividade e se forem fazer com um agente externo, também há um custo alto, pois as agências que criaram indicadores de impacto detêm direitos e exclusividades sobre eles na prestação de serviço e certificação. As certificações mostram conformidade de acordo com algumas regras, que costumam vir atreladas a um reconhecimento institucional.

A literatura de avaliação de políticas públicas também é relevante para o estudo das avaliações dos negócios sociais:

\begin{abstract}
"A avaliação é a fase do ciclo de políticas públicas em que o progresso de implementação e o desempenho da política pública são examinados com o intuito de conhecer melhor o estado da política que a gerou. É o momento-chave para a produção de feedback sobre as fases antecedentes.”(SECCHI, 2010, p. 49)
\end{abstract}

Alguns dos principais critérios de avaliação são eficiência econômica, eficácia e equidade. A política pública também pode ser analisada por indicadores que focam input (que mostra os esforços), output e resultado (que mostram as realizações).

Secchi (2010) ressalta o problema da multicausalidade, também presente nas avaliações de negócios sociais. Um resultado positivo alcançado pode não ser consequência direta de uma política e sim de diversos outros fatores. Muitas vezes é difícil isolar tais fatores. Outra questão característica das avaliações de políticas públicas é o inerente interesse político nos resultados, dado que são vários os atores potencialmente envolvidos com elas. É possível que isso ocorra nos negócios sociais, que também envolvem diversos stakeholders. De qualquer forma, independentemente dos interesses envolvidos, um ponto de atenção aos sistemas de avaliação é a objetividade de seus critérios.

Dias e Matos (2012) afirmam que a avaliação é fundamental para o sucesso de uma política pública, pois mostra ao gestor quais ações levam aos melhores resultados. Ela deve ser feita em todo o ciclo de políticas públicas. As avaliações ex-ante acontecem para conhecer melhor a população que deverá ser diretamente beneficiada e a adequar a política a ela. A avaliação intermediária ocorre durante a implementação da política, para acompanhar seu andamento. E depois que a política se encerra, ocorre a avaliação ex-post, que procura avaliar seu sucesso.

A avaliação de impacto social é de grande importância para os negócios sociais (OLIVEIRA FILHO; KIYAMA; COMINI, 2013). No próprio conceito de negócios sociais, está implícito que haverá a geração de um impacto positivo e melhoria da qualidade de vida de pessoas de baixa renda. Porém, o tema ainda não conseguiu se consolidar dentro ou fora da academia. Essa consolidação não depende apenas dos pesquisadores teóricos. Há pesquisas para mapear as práticas de avaliação de impacto sociais de negócios sociais, como a de Silva 
(2013) na área de saúde. Porém, os achados são ainda muito incipientes, o autor encontrou poucas tentativas de avaliação. Por esses motivos, o tema "impacto social" continua como uma referência na pesquisa, mas não como seu foco.

Marr (2006) afirma que na implantação de sistemas de indicadores, começa-se pelo que é mais facilmente medido ou quantificável e o que é mais difícil de medir é menos priorizado, tido como não importante ou até como inexistente. $\mathrm{O}$ impacto social devido à sua natureza mais qualitativa pode ser alvo dessa armadilha.

Tuan (2008) analisa oito tipos diferentes de indicadores de negócios e projetos sociais: análise de custo-efetividade, análise de custo-benefício, retorno social sobre o investimento, razão custo benefício da Fundação Robin Hood, razão da Fundação Acumen, retorno esperado da Fundação William and Flora Hewlett, custo por impacto do Center for High Impact Philanthropy e gráfico de bolha para investimento de fundações. A análise de custobenefício, compara o investimento com o benefício trazido pela atuação de um negócio social. Como os benefícios ou impactos são intrinsecamente sociais e não monetários é difícil monetizá-los e torná-los insumos das análises.

Carvalho, Hourneaux Jr., Ribeiro e Cintra (2014) pesquisaram como seria possível usar análises financeiras tradicionais em projetos sociais. Na investigação, foi identificado que a maior parte dos funcionários de projetos sociais enxerga que há uma demanda pela quantificação dos resultados dos projetos, especialmente no relacionamento com investidores. Os autores também simularam uma análise de valor presente líquido baseado em valores reais para os investimentos e retornos de um projeto de geração de renda para pessoas com baixa capacitação.

Porém, assim como Tuan (2008), os autores reconhecem que em projetos, programas ou empreendimentos sociais que lidam com causas mais subjetivas que a geração de renda, tais como direitos humanos, moradia, assistência social, entre outros, a transformação dos resultados em valores financeiros é bem mais complexa.

Tuan (2008) descreve várias questões técnicas importantes no que tange à avaliação, ainda não solucionadas na área social. Em sua maior parte, estas questões são originadas na prática de instituições voltadas ao apoio aos negócios sociais (por exemplo, Fundação Bill e Melinda Gates):

- Pressupostos: algumas intuições ou simples impressões são assumidas como verdade no campo social.

- Taxa Interna de Retorno: não há conformidade sobre qual taxa deve ser usada para trazer o valor futuro de um investimento ao valor presente líquido. 
- Horizonte de tempo a ser estudado: não há consenso sobre qual prazo deve ser usado para a análise do benefício. Por exemplo, no caso de um projeto social com foco em educação básica pode-se usar um horizonte de tempo de cinco, dez ou até vinte anos.

- Preços sombra: eles são o custo de oportunidade de um produto ou serviço que não possui valor de mercado, como o serviço de uma dona de casa ou o prejuízo causado pela ocorrência de um crime para a sua vítima.

- Interdependências: muitos benefícios dependem de fatores externos à interação entre o negócio social e o público beneficiado, por exemplo, o desempenho escolar de uma criança que recebe serviços de reforço escolar depende muito de como está a vida dela em outras áreas, por exemplo, no relacionamento com a família. Tais fatores raramente são medidos.

- Juízos de valor: alguns julgamentos são feitos de forma muito particular e não sistemática. Por exemplo, ao medir melhorias na saúde não se sabe ao certo se a cura de uma pessoa de 30 anos, que ainda estará em idade produtiva por décadas deve ter o mesmo peso na avaliação da cura de uma pessoa de 70 anos.

Em outra perspectiva mais ampla, a autora ainda apresenta outras questões e problemas: não padronização do uso de linguagem; não padronização de forma de mensuração no setor social; falta de dados de qualidade sobre impactos, resultados e custos; falta de incentivo para uma gestão transparente; não mensuração de consequências não esperadas; utilização inadequada da mensuração e custo de mensuração.

Gonin, Besharov, Smith e Gachet (2013) abordam os desafios e tensões ligados especificamente às avaliações de desempenho de organizações híbridas, como os negócios sociais. Organizações híbridas são as que combinam modelos de atuação e de criação de valor tradicionalmente separados, como uma missão de gerar melhoria de qualidade de vida de pessoas de baixa renda e a condução de atividades comerciais que geram retorno financeiro (GONIN, et al., 2013; BATTILANA, 2012).

Uma das tensões de desempenho identificada por Gonin et al (2013) aparece quando as organizações buscam objetivos conflitantes demandas inconsistentes vindas de diferentes stakeholders ou usam metodologias inadequadas para monitorar o desempenho. Os objetivos sociais costumam ser melhor avaliados a partir de métricas mais qualitativas e subjetivas. Há uma tendência em enfatizar medidas mais quantitativas e exatas em detrimentos das medidas qualitativas e de longo prazo de acordo com teorias de comportamento na tomada de decisão (GONIN et al., 2013). Isso pode levar a uma perda de prioridade dos aspectos sociais. 
Marr (2006) mostra que após a criação de indicadores, para que gerem melhorias de gestão é preciso que se aprenda com eles. Franco-Santos, Kennerley, Micheli, Martinez, Mason, Marr, Gray e Neely (2007) ressaltam que uma das consequências esperadas da avaliação de desempenho de negócios é o favorecimento da aprendizagem e melhorias. Os autores acreditam que seja pouco provável que o uso adequado da avaliação não gere aprendizagem organizacional e mais conhecimento sobre a organização.

Para que a aprendizagem ocorra, é fundamental que haja as condições necessárias, o que o autor chama de ambiente de estímulo à aprendizagem. Esse ambiente é evidenciado especialmente nos momentos de discussão sobre resultados em que diversas equipes de níveis hierárquicos distintos se reúnem para conversar sobre o desempenho da empresa. Marr (2006) salienta que é comum isso acontecer em reuniões, que mais parecem julgamentos, em que os funcionários se veem obrigados a explicar seus desempenhos, normalmente colocando a culpa no ambiente externo ou em outro departamento devido à pressão que recebem. Outro cenário comum são as reuniões pouco claras em que há tantos indicadores que não se sabe como eles se relacionam um com o outro, nem com o desempenho final da empresa (MARR, 2006).

No ambiente de estímulo à aprendizagem, essas reuniões não são chamadas de revisão, como nos casos anteriores, pois isso conota um olhar para o passado em vez de aprimoramentos para o futuro. Antes que elas aconteçam, todos que participarão já tiveram acesso aos resultados dos indicadores, e se reúnem com o propósito de aprenderem mais sobre o desempenho, em um ambiente de confiança. Neste ambiente, é comum a identificação de lições aprendidas a partir da análise do resultado das avaliações. O Instituto de Gerenciamento de Projetos (PMI) ${ }^{1}$ (2008) define lições aprendidas como a aprendizagem obtida a partir do desempenho em projetos ou processos.

Do apresentado, é possível identificar metodologias de avaliação de desempenho que também são aplicáveis aos negócios sociais e que serviram de base para o reconhecimento das metodologias encontradas no campo. A identificação de suas críticas é interessante para indagar os agentes pesquisados, como eles superam tais limitações e como pretendem evoluir nesse sentido.

\footnotetext{
1 "O Instituto de Gerenciamento de Projetos (Project Management Institute, PMI) é a uma das maiores associações para profissionais de gerenciamento de projetos. Nosso trabalho para a profissão auxilia mais de 700.000 membros, profissionais certificados e voluntários em praticamente todos os países do mundo a aumentar o sucesso das suas empresas, evoluir em suas carreiras e tornar a profissão mais madura.” (PMI, 2016)
} 


\subsection{Aprendizagem Organizacional}

Aprendizagem organizacional para Easterby-Smith, Burgoyne e Araujo (2001 ) é a forma e o contexto em que a aprendizagem ocorre dentro das organizações. Prange (2001) retoma diversas definições do conceito. Entre elas, em 1963, Cyert e March definiram aprendizagem organizacional como "o comportamento adaptativo das organizações ao longo do tempo" (p. 46). Essa definição é não é muito adequada para a pesquisa em questão, pois mostra que a aprendizagem especialmente como reativa, ou seja, acontece principalmente para consertar erros, e não para propor melhorias. Para este estudo, aprendizagem organizacional é melhor delimitada como "processo de construção social que responde a eventos internos e externos na organização, criando novas interpretações da realidade que são armazenadas na memória organizacional quando devidamente institucionalizadas" (AMORIM; FISCHER, 2009, p.121 a partir de PRANGE, 2001).

A literatura enfatiza que a aprendizagem organizacional é especialmente importante para a gestão de novos empreendimentos em ambientes dinâmicos (LI, CHEN, LIU, \& PENG, 2014), o que parece caracterizar muitos negócios sociais e o ambiente em que estão inseridos. Os mesmos autores mostram que a combinação de laços e aprendizagem organizacionais é importante para a captação efetiva de novas oportunidades. Ou seja, estas novas oportunidades podem ser encontradas em parcerias tanto com organizações semelhantes, como os próprios negócios sociais, quanto com outros stakeholders, como apoiadores e investidores. Tais oportunidades baseadas na troca de conhecimento e aprendizagem podem importar para a criação de novos espaços de melhoria.

A aprendizagem dentro das organizações ocorre nos níveis individual, grupal e organizacional (ANTONELLO, 2005). Prange (2001) retoma Fiol e Lyles (1985), segundo os quais, o resultante da aprendizagem organizacional é maior do que a soma das partes, ou seja, maior do que a combinação dos conhecimentos individuais de cada pessoa que participa dela.

O conhecimento se divide em dois tipos, tácito (aquele que não foi formalizado) e explícito (aquele que pode ser apreendido pela leitura de manuais, por exemplo). Para que a aprendizagem ocorra, especialmente a do conhecimento tácito, é necessário um ambiente adequado. Nesse ambiente, os relacionamentos são próximos e incentivados, há um senso de comunidade, há a identificação de um propósito comum e há uma visualização do todo em vez do isolamento em departamentos (MARR, 2006).

O processo de transformação do conhecimento tácito para o explícito é chamado de codificação e torna o conhecimento mais acessível a novos aprendizes (ABBAD; BORGES- 
ANDRADE, 2014). A codificação também é responsável por transformar a aprendizagem individual em conhecimento organizacional. Mesmo após a codificação, alguns conhecimentos não são tidos como válidos ou valorizados, por isso, nem tudo o que se aprende vira conhecimento organizacional.

A aprendizagem é tanto um processo quanto um resultado. Para Kolb (1984), o processo de aprendizagem passaria por: experimentar, refletir, pensar, agir. "As organizações aprendem quando têm capacidade para serem sensíveis às necessidades do meio (interno e externo), quando são capazes de utilizar o saber adquirido para incrementar a eficácia de suas respostas e de responder criativamente quando detectam erros" (ANTONELLO, 2005, p. 27). A utilização do saber adquirido seria evidenciada pelo aumento da eficácia. Para Knowles, Holton e Swanson (2005), a aprendizagem é verificada quando há uma mudança de comportamento que se mantém por certo período de tempo como resultado de uma experiência.

O processo de aprendizagem pode ser complexo e fonte de conflitos ou dilemas, especialmente em organizações que buscam dois propósitos, social e financeiro, como os negócios sociais. Gonin et al. (2013) mostram que existem quatro tipos de dilemas típicos do empreendedorismo social e alguns deles são relacionados à aprendizagem, estratégias de crescimento e ganho de escala.

Quanto aos dilemas ocasionados pela aprendizagem, eles acontecem porque pode haver divergências quanto ao horizonte de tempo de cumprimento e verificação de metas. As metas financeiras são mais fáceis de medir em curto prazo, já as sociais requerem mais tempo para medição, porém, são tão prioritárias quanto às financeiras. Isto pode causar tensões. Outro motivo de dilemas de aprendizagem são as estratégias de crescimento e ganhos de escala. Se por um lado, ao crescer a organização tende a aumentar o impacto a que se propõe, por outro, perde algumas vantagens das pequenas organizações sociais, tais como parcerias locais (GONIN et al., 2013).

Iizuka, Varela e Larroudé (2015) usaram o modelo desenvolvido por Gonin et al (2013) para analisar uma organização brasileira que apresenta propósitos financeiros e sociais, a Rede Asta que comercializa artesanato, muitos feitos de material reciclado e por pessoas de baixa renda. A organização atua por meio de uma empresa privada, que vende os produtos para revendedores, e por meio de uma instituição responsável por conectar e apoiar os artesãos.

Um dos dilemas encontrados no que tange à aprendizagem foi o perfil dos revendedores. A dúvida consistia em decidir se os revendedores seriam prioritariamente 
pessoas de baixa renda, que não consomem artesanato, mas teriam um aumento de renda, o que aumentaria o impacto social da Rede Asta, ou seriam pessoas de renda maior cujo meio social consome mais artesanato, o que seria financeiramente benéfico para a organização. Outro dilema está relacionado a como aprender a lidar com cada perfil de revendedor. Além disso, a organização aprende como valorizar sua marca, o que é fundamental para o avanço do negócio social, porém, envolve custos cujos benefícios acontecerão em longo prazo. Esse mesmo investimento poderia ser usado para a resolução de problemas sociais mais urgentes do negócio.

Pelo apresentado, a identificação de procedimentos voltados às melhorias em seus processos, que comumente ocorrem por experiências de aprendizagem, é relevante para os negócios sociais. De forma específica, foi de interesse desta pesquisa verificar se as iniciativas de melhoria têm por base processos de avaliação após os quais houvesse alguma reflexão sobre seus resultados. De certa forma, ao se pensar em conhecimentos válidos para organização, indaga-se até que ponto há interesse em aprender a avaliar os negócios sociais como fonte de aprendizagem. Em outras palavras, nos negócios sociais, eventuais atividades de avaliação provocariam reflexão e aprendizagem?

\subsection{Síntese de conceitos e definições}

No quadro a seguir são relacionados os conceitos principais visitados na revisão da literatura, qual definição será usada na pesquisa e com qual objetivo específico se relacionam, o que justifica sua apresentação na parte conceitual como ocorreu nos subtópicos anteriores.

Quadro 1- Quadro conceitual

\begin{tabular}{|l|l|l|}
\hline \multicolumn{1}{|c|}{ Conceito } & \multicolumn{1}{|c|}{ Definição } & $\begin{array}{l}\text { Com qual objetivo específico o conceito } \\
\text { se relaciona }\end{array}$ \\
\hline Negócios sociais & $\begin{array}{l}\text { "Organizações que têm o objetivo resolver } \\
\text { problemas sociais de forma eficiente e com } \\
\text { sustentabilidade financeira por meio de } \\
\text { mecanismo de mercado" (FISCHER e COMINI, } \\
\text { 2012, p. 367) }\end{array}$ & $\begin{array}{l}\text { Caracterizar o negócio social que faz } \\
\text { avaliação. }\end{array}$ \\
\hline $\begin{array}{l}\text { Avaliação de } \\
\text { negócios sociais }\end{array}$ & $\begin{array}{l}\text { Métodos para avaliar os resultados alcançados } \\
\text { pelo negócio social. }\end{array}$ & $\begin{array}{l}\text { Caracterizar e analisar os processos de } \\
\text { avaliação nos negócios sociais. } \\
\text { Identificar e caracterizar se os processos } \\
\text { de avaliação geram aprendizagem } \\
\text { organizacional na forma de lições } \\
\text { aprendidas. }\end{array}$ \\
\hline
\end{tabular}




\begin{tabular}{|l|l|l|}
\hline & $\begin{array}{l}\text { “[...] processo de construção social que responde } \\
\text { a eventos internos e externos na organização, } \\
\text { criando novas interpretações da realidade que são } \\
\text { armazenadas na memória organizacional quando } \\
\text { organizacional } \\
\text { devidamente institucionalizadas.” (PRANGE, } \\
\text { 2001 apud AMORIM; FISCHER, 2009, p.121). }\end{array}$ & $\begin{array}{l}\text { Identificar e caracterizar se os processos } \\
\text { de avaliação geram aprendizagem } \\
\text { organizacional na forma de lições } \\
\text { aprendidas. }\end{array}$ \\
$\begin{array}{l}\text { Identificar e analisar se existem barreiras } \\
\text { ou dificuldades para os processos de } \\
\text { avaliação. }\end{array}$ \\
\hline
\end{tabular}

Fonte: Adaptado pelos autores de FISCHER; COMINI, 2012; PRANGE, 2001; AMORIM; FISCHER, 2009

No que diz respeito aos negócios sociais, a busca literária foi relevante para indicar quais aspectos deveriam ser buscados para identificar esse tipo de negócio e mostrar o quão próximo do que a teoria coloca como ideal ele está. Em relação à avaliação de negócios, foi importante identificar quais fatores merecem mais atenção para descrever uma avaliação adequada e que gera melhorias e aprendizagem. Ainda sobre o contexto de negócios sociais, neste trabalho, o termo "negócios sociais" também será tratado apenas como "negócios", para evitar repetições e ajudar na fluidez do texto. Pelo mesmo motivo, "fundo de investimento" e “investidores” também serão tratados como sinônimos.

A busca do que a teoria expõe como aprendizagem organizacional e quais são suas nuances ajudaram a identificar e interpretar o fenômeno ainda pouco compreendido a que ela se refere e se está relacionada com a avaliação do negócio. Por último, o estudo da avaliação também ajuda a compreender porque há resistência em fazê-la.

A partir deste quadro conceitual, ao final da metodologia será apresentado um novo quadro que mostra como cada objetivo específico será pesquisado, por meio de quais indagações especificamente e como isso se relaciona com a literatura levantada. 


\section{METODOLOGIA}

Esta sessão apresenta a metodologia abordada na pesquisa, as razões de sua escolha, bem como se deu a coleta e a análise dos dados levando em conta o objetivo geral e os objetivos específicos. Ao final, há a apresentação de um levantamento preliminar, o qual foi realizado com atores do campo antes do delineamento final da metodologia para verificar se ela era adequada.

\subsection{Caracterização da Metodologia}

Como finalidade, essa pesquisa se enquadrou na categoria qualitativa, que está mais focada na profundidade e não na extensão, como é a quantitativa (YIN, 2010). A pesquisa qualitativa se caracteriza pelo interesse em entender o fenômeno como um todo, como as partes se relacionam e influenciam mutuamente, e o contexto é tido como relevante, não como algo a ser isolado (KNOWLES; HOLTON; SWANSON, 2005).

Esta pesquisa apresentou ainda um viés exploratório-descritivo. Exploratório porque ainda não se dispõe de um grande conhecimento sobre o assunto e um dos intuitos dela é servir de base para outras, e descritivo porque procurar descrever, caracterizar como determinada situação, no caso a avaliação de negócios sociais, ocorre (CHAROUX, 2006).

A estratégia de pesquisa adotada foi o estudo de caso, porque "são úteis para proporcionar uma visão mais clara acerca de fenômenos pouco conhecidos" (GIL, 2009, p. 14). Como essa pesquisa tratou de um fenômeno recente e muito pouco estudado na academia, julgou-se que o estudo de caso fosse o delineamento mais adequado para ela.

O que se almejou com os estudos de caso foi "uma generalização analítica, que tem como propósito construir ou expandir teorias" (GIL, 2009, p. 15). Outra de suas características foi "proporcionar nova compreensão do fenômeno e gerar inquietações no pesquisador, estimulando-o a desenvolver novas pesquisas" (GIL, 2009, p. 16), como a contribuição acadêmica desse trabalho foi também servir de base para outras pesquisas sobre um tema pouco explorado, esse foi outro ponto de adequação.

O delineamento mais específico foi de estudo de casos múltiplos integrados, em que mais de um caso foi pesquisado e as unidades de pesquisa não eram todas da mesma natureza (YIN, 2010), pois houve negócios sociais, fundos de investimento e organizações avaliadoras. “A evidência dos casos múltiplos é, muitas vezes, considerada mais vigorosa e o estudo, em geral é, por essa razão, visto como mais robusto" (YIN, 2010, p. 85). Como avaliação e aprendizagem em negócios sociais ainda é um assunto pouco explorado na literatura 
brasileira, foi interessante apresentar mais de um caso. A escolha de casos múltiplos se justificou pela necessidade de replicação teórica, ou seja, houve o interesse em verificar se um fenômeno acontecia em mais de um caso, como e se era semelhante ou contrastante ao anterior.

Os estudos de caso são alvos de diversas críticas. Uma delas diz respeito ao isolamento do estudo do caso particular em relação à discussão teórica corrente sobre o tema (ALVES-MAZZOTTI, 2006). Essa pesquisa usou continuamente a abordagem de comparação com a teoria, para evitar esse problema.

\subsection{Escolha dos Casos}

A escolha dos casos que foram estudados foi intencional e partiu da indicação de entrevistados dos fundos de investimento. Para coletar os dados, foi feita uma busca pelos investidores constantes pelo Guia 2.5, uma publicação voltada para os empreendedores que apresenta diversas organizações de apoio e como cada um deles pode auxiliar um negócio social, além de diversas outras informações práticas. Esse guia foi elaborado pelo Instituto Quintessa com o objetivo de auxiliar os negócios sociais a compreenderem melhor o ambiente em que estão inseridos (INSTITUTO QUINTESSA, 2015) e foi lançado em outubro de 2015. O Guia foi usado por ser considerado um filtro de indicação das iniciativas de maior destaque no setor.

Ao final do Guia 2.5 há a indicação de 23 iniciativas de financiamento e investimento para conhecer. Todas elas foram pesquisadas por meio do site entre os meses de dezembro de 2016 e janeiro de 2017. Mais oito iniciativas foram incluídas por conhecimento prévio da pesquisadora sobre o campo. Das 31 iniciativas resultantes, verificou-se que 21 não se encaixavam no escopo da pesquisa por não investirem propriamente em negócios sociais ou não atuarem no Estado de São Paulo.

Todas as demais iniciativas foram contatadas por telefone. Destas, quatro não responderam ou não puderam participar e seis foram analisadas neste trabalho. $\mathrm{O}$ conjunto final selecionado propiciou a reprodução de resultados contrastantes, uma vez que três fundos investem por meio de sociedade no negócio, dois por meio de empréstimo e um usa um modelo híbrido. Apesar disso, houve saturação dos dados nas últimas entrevistas, o que justiçou o fim da busca por novos casos de investidores

A partir da pesquisa com investidores, foram buscados os negócios sociais que tinham, segundo os seus respectivos investidores, práticas e/ou rotinas de avaliação estruturadas. Novamente foi usado um filtro, o da percepção dos fundos, pois o levantamento preliminar 
(abordado no final do tópico 4.4) indicou que apenas os negócios sociais mais maduros fariam algum tipo de avaliação.

Além dos negócios indicados, dois investidores sugeriram duas organizações que também deveriam ser pesquisadas. Uma realiza pesquisas para OSCs (organizações da sociedade civil) e empresas sobre as classes de renda mais baixa e a outra é a certificadora do movimento B, que será explicado ao abordar essa organização.

\subsection{Coleta de Dados}

Como método de coleta de dados, foram usadas a análise documental e a entrevista aberta. O principal tipo de análise documental foi a partir do que Yin (2010) chama de documentação, que foi sobre documentos internos e de divulgação na mídia. $O$ autor recomenda que se faça uma triagem para a seleção dos documentos mais centrais à investigação e posterior leitura e revisão.

A entrevista aberta em que "tanto as questões quanto a sequência são predeterminadas, mas os entrevistados podem responder livremente" (GIL, 2009, p. 64) foi escolhida como método, porque possibilita o entendimento mais profundo de como os gestores enxergam a aprendizagem organizacional, a avaliação dos negócios sociais e quais procedimentos são usados em sua gestão. "Os entrevistados bem-informados podem proporcionar insigths importantes sobre esses assuntos ou eventos" (YIN, 2010, p. 135). Easterby-Smith, Thorpe e Lowe(1991) afirmam que esse tipo de entrevista é recomendado quando há uma necessidade de compreensão do contexto da situação estudada.

"Existe a possibilidade de as pessoas fornecerem respostas falsas" (GIL, 2009, p. 63), porém, isso foi evitado ao comparar os dados com os obtidos pela análise documental. $\mathrm{Ou}$ seja, houve uma comparação de dados. Antes das entrevistas, houve uma busca por documentos, tais como relatórios financeiros e de desempenho, publicações externas sobre as organizações, entre outros.

Yin (2010) comenta que os documentos podem corroborar ou contradizer o conteúdo que foi dito nas entrevistas. No segundo caso, é fundamental "perseguir o problema investigando mais profundamente" (YIN, 2010, p. 114). Ele aponta ainda que um dos princípios para a coleta de dados em estudos de caso é a utilização de várias fontes de evidência.

A intenção inicial era abordar os entrevistados já com informações prévias sobre as organizações a partir da análise de documentos, mas isso não foi possível. Diversos 
documentos eram sigilosos e todos só estiveram à disposição da pesquisadora após as entrevistas.

Apenas os conteúdos disponibilizados nos websites das organizações foram analisados previamente, os quais geraram o material para as entrevistas. Muitas questões que seriam respondidas por meio dos materiais impressos ou virtuais foram esclarecidas também nas entrevistas. Ao final, apenas um caso não forneceu os documentos por alegar sigilo.

Easterby-Smith, Thorpe e Lowe (1991) chamam atenção para o viés que pode ocorrer nas entrevistas e como evitá-lo. Para os autores, uma das estratégias para isso é certificar-se que o entrevistado compreendeu corretamente a pergunta e se sente livre para emitir sua opinião. Para tal, foi realizado um pré-teste da entrevista com duas organizações, sendo uma social e a outra um negócio social. Por último, Easterby-Smith, Thorpe e Lowe mostram a importância da ética no procedimento de pesquisa principalmente no que concerne a sigilo e como a pesquisa pode afetar a relação entre os entrevistados em uma mesma organização.

A triangulação dos casos se deu então por fontes. As fontes de cada caso foram a entrevista com o gestor do fundo de investimento e do negócio social e os documentos. Havia a sugestão de usar como fonte de evidência a observação, porém, uma pesquisadora mais experiente deste ecossistema alertou que não seria possível acompanhar momentos em que a avaliação e a aprendizagem fossem trabalhadas, por sigilo das organizações.

O quadro a seguir mostra como cada objetivo específico foi buscado a partir de análise documental ou entrevista nos negócios sociais. Além disso, o quadro apresenta como cada pergunta do roteiro foi formulada a partir da teoria, necessidade de caracterização simples ou a partir levantamento empírico preliminar. Os roteiros de análise documental e de entrevista utilizados com investidores e negócios sociais estão expostos no apêndice. 
Quadro 2 - Relação entre objetivos, questões de roteiro e literatura

\begin{tabular}{|c|c|c|c|}
\hline Objetivo específico & $\begin{array}{l}\text { Roteiro de análise } \\
\text { documental ou } \\
\text { entrevista }\end{array}$ & Pergunta & Referência da literatura \\
\hline \multirow{8}{*}{$\begin{array}{l}\text { Caracterizar o negócio } \\
\text { social que faz avaliação }\end{array}$} & Documental & 1. Qual é o negócio? & $\begin{array}{l}\text { Pergunta de caracterização } \\
\text { dos casos. }\end{array}$ \\
\hline & Documental & 2. Qual é o ramo de atuação? & JP Morgan, 2007. \\
\hline & Documental & 3. Qual é a missão? & JP Morgan, 2007. \\
\hline & Documental & $\begin{array}{l}\text { 4. A maior parte do público } \\
\text { atendido pertence à base da } \\
\text { pirâmide? }\end{array}$ & $\begin{array}{l}\text { Yunuseta.1,2010; Acumen, } \\
2014 .\end{array}$ \\
\hline & Documental & $\begin{array}{l}\text { 5. Como a base da pirâmide é } \\
\text { beneficiada? }\end{array}$ & $\begin{array}{l}\text { Yunus e Weber, 2007; JP } \\
\text { Morgan, 2007; Agnihotri, } \\
2013\end{array}$ \\
\hline & Documental & 6.Qual é o número de clientes? & Tashman eMarano, 2010. \\
\hline & Documental & $\begin{array}{l}\text { 7. O negócio consegue manter } \\
\text { suas atividades sem } \\
\text { investimentos externos? Se não, } \\
\text { há um planejamento para isso? }\end{array}$ & Fischer eComini, 2012. \\
\hline & Documental & $\begin{array}{l}\text { 8. O negócio se relaciona com } \\
\text { investidores? Como? Houve } \\
\text { alguma exigência para se ter } \\
\text { acesso ao investimento? }\end{array}$ & $\begin{array}{l}\text { Relevante devido ao } \\
\text { resultado do levantamento } \\
\text { preliminar. }\end{array}$ \\
\hline \multirow{5}{*}{$\begin{array}{l}\text { Caracterizar os } \\
\text { processos de avaliação }\end{array}$} & Documental & $\begin{array}{l}\text { 9. O negócio social utiliza um } \\
\text { método formal para avaliação } \\
\text { de sua atuação? Qual? }\end{array}$ & $\begin{array}{l}\text { Pergunta de caracterização } \\
\text { dos casos. }\end{array}$ \\
\hline & Documental & $\begin{array}{l}\text { 10. O método de avaliação foi } \\
\text { desenvolvido pela própria } \\
\text { empresa ou é externo? Se for } \\
\text { externa, porque ela foi } \\
\text { escolhida? }\end{array}$ & $\begin{array}{l}\text { Relevante devido ao } \\
\text { resultado do levantamento } \\
\text { preliminar. }\end{array}$ \\
\hline & Documental & $\begin{array}{l}\text { 11. Quais aspectos do } \\
\text { desempenho são avaliados? Há } \\
\text { indicadores financeiros e não } \\
\text { financeiros? Há exemplos de } \\
\text { cada? }\end{array}$ & $\begin{array}{l}\text { Secchi (2010) Marr (2006); } \\
\text { Carvalho, Hourneaux Jr., } \\
\text { Ribeiro e Cintra (2014). }\end{array}$ \\
\hline & Entrevista & $\begin{array}{l}\text { 1. Para que a avaliação é } \\
\text { usada? }\end{array}$ & Marr, 2006. \\
\hline & Entrevista & $\begin{array}{l}\text { 2. A iniciativa de formalizar } \\
\text { a avaliação partiu do próprio } \\
\text { negócio ou de algum fator } \\
\text { externo? }\end{array}$ & $\begin{array}{l}\text { Relevante devido ao } \\
\text { resultado do levantamento } \\
\text { preliminar. }\end{array}$ \\
\hline
\end{tabular}


Quadro 2 - Relação entre objetivos, questões de roteiro e literatura

\begin{tabular}{|c|c|c|c|}
\hline Objetivo específico & $\begin{array}{c}\text { Roteiro de análise } \\
\text { documental ou } \\
\text { entrevista }\end{array}$ & Pergunta & Referência da literatura \\
\hline \multirow{3}{*}{$\begin{array}{l}\text { Caracterizar os } \\
\text { processos de avaliação }\end{array}$} & Documental & $\begin{array}{l}\text { 9. O negócio social utiliza um } \\
\text { método formal para avaliação } \\
\text { de sua atuação? Qual? }\end{array}$ & $\begin{array}{l}\text { Pergunta de caracterização } \\
\text { dos casos. }\end{array}$ \\
\hline & Entrevista & $\begin{array}{l}\text { 3. Há um custo envolvido no } \\
\text { processo? Como ele é gerido? }\end{array}$ & Marr, 2006 \\
\hline & Entrevista & 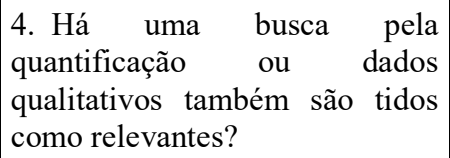 & $\begin{array}{l}\text { Carvalho, Hourneaux Jr., } \\
\text { Ribeiro e Cintra (2014) }\end{array}$ \\
\hline \multirow{6}{*}{$\begin{array}{l}\text { Identificar e } \\
\text { caracterizar se os } \\
\text { processos de avaliação } \\
\text { geram lições aprendidas }\end{array}$} & Entrevista & $\begin{array}{l}\text { 5. Como você caracteriza a } \\
\text { rotina na organização quanto a } \\
\text { incentivos de aprendizagem? Há } \\
\text { responsabilização por erros? } \\
\text { Novas formas de fazer as } \\
\text { mesmas atividades são } \\
\text { incentivadas? }\end{array}$ & $\begin{array}{l}\text { Marr, 2006; Knowles, } \\
\text { Holton e Swanson } 2005 .\end{array}$ \\
\hline & Entrevista & $\begin{array}{l}\text { 6. Há reuniões para avaliação } \\
\text { de resultados? Como são? }\end{array}$ & Marr, 2006. \\
\hline & Entrevista & $\begin{array}{l}\text { 7. Você acredita que houve } \\
\text { alguma lição aprendida no } \\
\text { processo de implementação } \\
\text { análise dos resultados da } \\
\text { avaliação? Quais? Como foi } \\
\text { esse processo de reflexão? }\end{array}$ & Marr, 2006; PMI, 2008. \\
\hline & Entrevista & $\begin{array}{l}\text { 8. E no estudo dos resultados } \\
\text { da avaliação, houve lições } \\
\text { aprendidas? Quais? Como foi } \\
\text { esse processo de reflexão? }\end{array}$ & Marr, 2006; PMI, 2008. \\
\hline & Entrevista & $\begin{array}{l}\text { 9. Houve alguma mudança no } \\
\text { comportamento de vocês a } \\
\text { partir das avaliações? }\end{array}$ & $\begin{array}{l}\text { Knowles, Holton e } \\
\text { Swanson, } 2005 .\end{array}$ \\
\hline & Entrevista & $\begin{array}{l}\text { 10. Há dificuldades para coleta } \\
\text { e análise dos dados da } \\
\text { avaliação? Quais? } \\
\text { a. Como elas são superadas? } \\
\text { b. Qual seria uma solução ideal } \\
\text { para superá-las? }\end{array}$ & $\begin{array}{l}\text { Comini, Barki e Aguiar, } \\
2012 .\end{array}$ \\
\hline
\end{tabular}

Fonte: dados da pesquisa 


\subsection{Análise de Dados}

Para análise dos resultados de um estudo de caso, Yin (2010) sugere que o pesquisador, antes mesmo de coletar os dados, adote uma das três estratégias: basear- se em proposições teóricas, pensar em explanações concorrentes ou desenvolver uma descrição de caso. Como não há ainda muitas explicações das razões pelas quais os negócios sociais aprendem ou não a partir de avaliações, a estratégia mais adequada para essa pesquisa foi a descrição de caso. A partir daí, foram sugeridas explicações para o contexto específico dos negócios sociais e sugeridas consequências para a realidade encontrada em campo.

Para a análise dos dados desse trabalho, foi usada a análise de conteúdo (BARDIN, 2011). Segundo a própria autora, essa análise é "um conjunto de técnicas de análise das comunicações. Não se trata de um instrumento, mas de um leque de apetrechos; ou, com maior rigor, será um único instrumento, mas marcado por uma grande disparidade de formas e adaptável a um campo de aplicações muito vasto: as comunicações" (grifos no original, p.33). Assim, a análise de conteúdo foi usada para analisar tanto os dados coletados por análise documental quanto os obtidos pelas entrevistas.

Após a realização das entrevistas, elas foram transcritas e analisadas. Segundo Gil (2009), é importante criar categorias analíticas, que devem refletir o propósito da pesquisa, formar um sistema coerente, ser mutuamente excludentes e coletivamente exaustivas. Bardin (2011, p. 147) afirma que as categorias são "classes, as quais reúnem um grupo de elementos [...] sob um título genérico, agrupamento esse efetuado em razão das características comuns destes elementos". E que a categorização "tem como primeiro objetivo [...] fornecer, por condensação, uma representação simplificada dos dados brutos" (ibidem, p. 149).

De acordo com Selltiz, Jahoda, Deutsch e Cook (1959), deve-se tomar por base a questão de pesquisa e o referencial teórico para a criação e classificação de categorias. Os autores mostram que para criar as categorias o primeiro passo é uma leitura atenta que possa dar indícios de quais agrupamentos podem existir. Os critérios de categorização podem ser, entre outros, semânticos, em que os agrupamentos são feitos de acordo com os significados (BARDIN, 2011).

Gil (2009) apresenta táticas para dar significado aos dados, como: "identificação de padrões e temas, agrupamento, contagem, estabelecimento de comparação e contrastes, repartição de variáveis, identificação de relações entre variáveis, identificação de variáveis intervenientes e construção da coerência conceitual teórica" (p. 109-110).

A partir do estudo da literatura sobre análise de conteúdo, a condução desta técnica na pesquisa consistiu em leituras das transcrições das entrevistas para identificar as falas 
correspondentes a cada categoria. Em seguida, elas foram tabuladas e comparadas, de forma que se extraiu uma síntese da fala de uma organização em relação a todas suas respostas e outra síntese de todas as respostas dadas pelas diferentes organizações a cada pergunta. Os trechos mais importantes de cada entrevista foram usados como referência para a análise no software NVivo, que possibilitou outra abordagem do conteúdo com a geração de representações visuais que serão apresentadas no tópico 6 .

\subsection{Consultas Iniciais ao Campo}

Para este estudo, foram realizadas consultas iniciais ao campo de pesquisa por meio de entrevistas. Os entrevistados observaram que poucas são as organizações capazes de se dedicar a medir o impacto que geram, como pode ser visto no quadro 3 neste tópico. Ou seja, há uma dificuldade tanto acadêmica quanto prática.

Consultas preliminares ao campo com apoiadores e investidores do ecossistema de negócios sociais foram realizadas. A maior parte deles listada no Guia 2.5, foram contatadas por telefone, e-mail ou pessoalmente. O roteiro utilizado nas entrevistas está no Apêndice 1. Foi possível identificar que poucos medem o impacto de forma concreta e profunda.

Houve uma receptividade positiva em relação à pesquisa, as organizações têm interesse em compreender melhor o impacto dos negócios sociais. Porém, três afirmaram que não teriam muito a acrescentar como objeto de pesquisa, pois ainda medem o impacto de forma muito elementar. Algumas organizações contatadas usam avaliações financeiras ou de gestão como forma de aproximação, partindo do pressuposto que se o negócio vai bem, deve estar gerando um impacto positivo relevante. Há uma dificuldade geral em avaliar que parece refletir na ausência de mecanismos de avaliação mais elaborados.

Outro dado percebido foi que apoiadores que lidam com negócios sociais em uma fase mais avançada, em que estão totalmente implementados, tendem a focar mais no impacto do que os apoiadores que trabalham com os negócios quando eles ainda são ideias. O investidor contatado parece ser um stakeholder mais preocupado em mensurar impacto do que os apoiadores, como o que indicam Barki et al (2015).

Nota-se que há contato entre as diversas organizações e uma sabe como as outras atuam, porém, como os focos de atuação se diferem em alguns aspectos, não parece haver competição forte entre eles. Por último, há uma busca por aprendizagem quando uma contata a outra. "[A aprendizagem] é constante e a cada projeto" (entrevistado Impact Hub). Isso 
acontece porque a população com quem eles estão lidando está em ambientes bastante mutáveis.

O quadro a seguir resume o que foi encontrado nessa primeira busca:

Quadro 3 - Principais considerações das organizações contatadas

\begin{tabular}{|c|c|c|}
\hline Tipo & Organizações & Observações \\
\hline \multirow{4}{*}{$\begin{array}{l}\frac{\dot{0}}{0} \\
\frac{\pi}{0} \\
\frac{\partial}{2} \\
\frac{\alpha}{4}\end{array}$} & Artemísia & $\begin{array}{l}\text { Usam a lógica de que se a empresa é de impacto, quanto melhor seu } \\
\text { desempenho financeiro, maior o impacto. Os próprios negócios não se } \\
\text { avaliam. } \\
\text { Não há uma metodologia estruturada para isso. As avaliações são caras. Não } \\
\text { são os próprios negócios que arcam com o custo financeiro. }\end{array}$ \\
\hline & Impact Hub & $\begin{array}{l}\text { "O que não se tem certeza é substituído por fé. [...] No Brasil, não conhecer o } \\
\text { modelo do próprio negócio tradicional ou social é muito comum." } \\
\text { Para alguns empreendedores sociais, falar em métricas financeiras é uma } \\
\text { ofensa. } \\
\text { "Eles esquecem que antes de ser social, é um negócio." }\end{array}$ \\
\hline & $\begin{array}{l}\text { Instituto } \\
\text { Quintessa }\end{array}$ & $\begin{array}{l}\text { Acreditam que os investidores deveriam pagar para um agente externo medir } \\
\text { impacto dos negócios sociais. }\end{array}$ \\
\hline & Social Good & $\begin{array}{l}\text { Os negócios e todos os empreendedores sociais estão interessados em medir o } \\
\text { impacto. Porém, essa atividade é muito intensiva no uso de diversos recursos. } \\
\text { E, mesmo assim, as conclusões poderiam ser incertas. Para os apoiadores é um } \\
\text { pouco mais fácil medir, pois podem ter um funcionário alocado para isso. } \\
\text { Porém, o foco da avaliação dos apoiadores é no impacto causado nos } \\
\text { empreendedores, e não no cliente final da base da pirâmide. }\end{array}$ \\
\hline 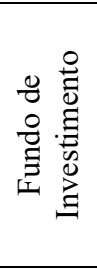 & Bemtevi & $\begin{array}{l}\text { "Os investidores têm sim buscado concretizar a realização de impacto social. } \\
\text { O desenvolvimento de indicadores, principalmente por um processo de } \\
\text { padronização para permitir a comparação, é tema de várias instituições. Mas é } \\
\text { muito difícil padronizar." } \\
\text { "A combinação entre investimento tradicional e social gerou o Impact } \\
\text { investment, que propõe causar um impacto social e gerar retorno financeiro é o } \\
\text { primeiro degrau. E neste caso a mensuração de impacto é muito importante." }\end{array}$ \\
\hline
\end{tabular}

Fonte: Dados da pesquisa 


\section{RESULTADOS}

Neste tópico são apresentados os fundos de investimento pesquisados nos casos, os negócios nos quais eles investem ou emprestam capital financeiro e mais duas organizações avaliadoras, totalizando 14 organizações pesquisadas para os 6 estudos de caso (cada caso é composto pelo negócio social, o investidor e em duas ocasiões, por organizações que avaliam também). Eles são apresentados nessa ordem que é a mesma em que foram contatados. Também serão descritas as características das organizações, suas missões, ações e o que se destacou na análise de seus dados em relação às outras organizações do mesmo tipo.

O quadro a seguir mostra os fundos de investimento e os negócios em que cada um investe. As empresas com asterisco possuem a certificação de empresa B, ou seja, elas se comprometem institucionalmente com as consequências de suas ações e pretendem resolver problemas sociais e ambientais. As empresas B são reguladas e certificadas pelo Sistema B. Esta última também foi pesquisada e está descrita no item 5.3.1 junto com a Plano CDE que avaliou o negócio social Vivenda e, por isso, também entrou no grupo das organizações pesquisadas.

Quadro 4 - Relação de investidores e negócios investidos

\begin{tabular}{|l|l|l|l|l|l|l|}
\hline Investidor & Bemtevi & Dínamo* & GAG & MOV* & SITAWI & Vox* \\
\hline Negócio investido & PanoSocial & Vivenda & Glic online & Triciclos* & CIES & Tem \\
\hline
\end{tabular}

Fonte: Dados da pesquisa

Legenda: os asteriscos indicam empresas B

\subsection{Fundos de Investimento}

Neste tópico serão apresentados os fundos de investimento pesquisados nos casos. Primeiro, há a descrição de cada organização com algumas características que se destacaram em relação às demais, quais são os requisitos para investir em um negócio e como são feitas as avaliações. Depois há uma comparação de todos os fundos de investimento pesquisados.

\subsubsection{Descrição dos investidores}

\subsubsection{Bemtevi}

A Bemtevi é uma organização que empresta capital financeiro a negócios sociais. Ela iniciou suas atividades em 2015 e efetuou o primeiro investimento em negócio social em 
dezembro de 2016, nesse período houve o levantamento de recursos financeiros e a preparação do negócio escolhido para receber o investimento, ela é a investidora mais nova.

O fundo capta recursos financeiros que são, em parte, investidos em uma aplicação financeira que paga os custos da estrutura da organização e possíveis inadimplências. A outra parte dos recursos é emprestada a negócios que já passaram pela análise dos gestores Bemtevi, de um comitê e de um conselho (cujos integrantes podem ser consultados no site da organização). Os investidores do fundo recebem o montante inicial investido, mas não esperam juros e sim impacto social como retorno do valor investido. Os indicadores e metas sociais e ambientais são descritos no contrato de empréstimo do fundo para o negócio. Caso o negócio não cumpra as metas, ele paga juros sobre o empréstimo que fica com a Bemtevi e não com os investidores.

A Bemtevi propõe um papel de apoio e assessoria aos negócios sociais (BEMTEVI, 2017) para que evitem pagar juros pelos empréstimos. E também apoia organizações que não estejam prontas para receberem seus empréstimos. No par analisado pela pesquisa, o fundo se mostrou muito presente e disposto a apoiar o negócio, porque foi o primeiro caso de empréstimo. O entrevistado acredita que nos próximos casos, o apoio deve ser mais de feedback para o negócio do que de construir junto com o negócio alguns indicadores e processos de avaliação e gestão.

Outra mudança resultante de uma lição aprendida em relação a esse primeiro caso deve ser colocar mentores, pessoas experientes que apoiam e auxiliam o aprendizado, como foco do papel de apoio aos negócios, pois os gestores do fundo aprenderam que a proximidade pode atrapalhar na cobrança de metas. "A gente estava muito como consultor da PanoSocial e agora, a gente está tentando trazer empresas ou mentores pra fazer esse papel, também pra gente ter um papel um pouco mais de cobrança em cima disso" (entrevistado PanoSocial). Outras lições aprendidas foram combinar o que será medido antes de fazer o empréstimo, por uma questão de atenção do negócio e que é importante a participação de negócio e investidor na definição de metas.

\subsubsection{Dín4mo}

O processo da Dín4amo é um pouco diferente dos demais investidores. A Dín4mo é tida como "suporte ao empreendedor" no Guia 2.5 e eles realmente fazem um trabalho mais focado em aceleração do que outros fundos de investimento pesquisados. Apenas depois de quatro ou cinco meses é possível saber se querem investir no negócio que estão acelerando “A gente só consegue saber depois do quarto ou quinto mês, porque para a gente é muito 
importante mais do que conhecer em teoria o modelo, é ver como ele acontece na prática." (Entrevistado Dín4mo). Um fator importante para tomar essa decisão é a capacidade de mudança e adequação do negócio se essa for a resposta necessária ao que o mercado pede:

"Então, para a gente, é muito importante conhecer o time que está botando de pé esse negócio e ver como esse modelo está rodando com suas eficiências ou ineficiências, com seus desafios e gargalos, etc para a gente ter a sensibilidade da atratividade, da complexidade e da capacidade do time de lidar com esses desafios. O problema maior do modelo não é ele estar errado, é ele estar engessado porque o time está abraçado nele e não quer pivotar ou fazer os ajustes necessários, isso acontece para caramba" (Entrevistado Dín4mo)

Se a Dín4mo for mesmo investir, a organização traz um grupo de investidores por meio de crowdequity na plataforma Broota, se não, ajudará o negócio a se apresentar para outros investidores. O crowdequity é um investimento coletivo que pode ser feito por pessoas físicas e jurídicas em pequenos volumes individuais. Em determinados prazos e acontecimentos, cada investidor individualmente decide se quer continuar sócio ou receber de volta o valor investido, como se ele tivesse sido apenas um empréstimo, e sair da sociedade.

Sobre a avaliação, durante o período de aceleração, com certa periodicidade, são definidas tarefas para o time empreendedor e o acompanhamento é feito semanalmente por conversas. Durante o período de investimento, o negócio envia reportes trimestrais para os investidores. A própria Dín4amo coleta dados de avaliação diretamente com o cliente final por meio de conversas informais.

A Dín4mo é certificada pelo Sistema B e pretende renovar a certificação constantemente. A Dín4mo acredita que essa certificação ajuda as organizações a refletirem sobre questões interessantes para o setor de negócios sociais.

Um aprendizado que tiveram ao longo da evolução da Dín4mo foi perceber a importância de ter uma área de governança nos negócios sociais. Então, na ocasião das entrevistas uma parte do programa de aceleração consistia em capacitar o negócio para criar e gerir a área de governança. Outro aprendizado foi a importância de personalizar o programa para as dificuldades e necessidades de cada empreendedor, respeitando seus tempos.

O entrevistado acredita que haverá uma onda de aprendizagem no setor de negócios sociais no Brasil quando o país tiver o primeiro caso de sucesso emblemático que atenda ao requisito de alcance de escala por meio de seu modelo de negócio:

\footnotetext{
"Talvez de forma mais genérica, eu acho que a gente precisa, no Brasil, mais rapidamente, conseguir trazer cases de negócios de impacto, que demonstrem evidências de que deram certo, eu acho que isso vai gerar uma nova onda de aprendizado. (...) Então... acho que isso vai ser muito importante para o campo porque a gente tem o que isso origina de aprendizado, a gente tem o que isso destrava daquelas pessoas que por não ter um case sempre dizem "me mostra um
} 
case, que aí eu vou" tem sempre aqueles que vão depois, você precisa gerar evidências disso." (Entrevistado Dín4mo)

\subsubsection{GAG}

A GAG é um fundo focado na área de saúde, mas já investiu em outros setores, como educação, e ainda tem recursos em negócios remanescentes da época em que tinha uma atuação mais ampla. Para escolher em quais negócios deve investir, não há um processo seletivo formalizado. A maior parte dos negócios chega a eles com a chancela de algum contato em comum da rede de negócio e da GAG. Depois, a GAG avalia o empreendedor e se ele tem como gerir o negócio, potencial de crescimento do negócio, qual problema ele resolve e como.

O fundo investe com participação societária e também com dívida conversível, esse último método é o mesmo usado pela Dín4mo. Para o fundo, é primordial que ele possa participar da gestão do negócio, a GAG não aceita investir quando o empreendedor não está aberto para essa participação. Ela costuma participar mais da parte estratégica do que operacional, mas o apoio em gestão varia com a demanda do empreendedor. Os gestores do fundo estão fisicamente bastante presentes nos negócios tanto em visitas quanto em espaços de trabalho compartilhados.

No caso do negócio entrevistado com o qual se relaciona, o GlicOnline, o fundo assumiu a operação da empresa, pois constatou que os empreendedores originais não se dedicariam exclusivamente ao negócio. Os empreendedores do negócio fizeram um esforço de pesquisa e criação de um aplicativo que auxiliasse no tratamento de diabetes, financiado pela Fundação de Amparo à Pesquisa do Estado de São Paulo. Porém, os criadores do aplicativo já tinham outras carreiras profissionais e decidiram continuar com elas. Então, a GAG encontrou parceiros que se identificavam com a causa do negócio e entregou a responsabilidade de gestão para eles:

\footnotetext{
"No caso do GlicOnline, tinha muito essa questão de a gente criar metas de tudo e as coisas não andavam da forma que a gente gostaria, (...) e aí começou a ter alguns problemas de gestão mesmo, a fundadora, ela trabalha, então assim, ela tem consultório, ela é muito envolvida com a causa de diabetes. Para gente fazia muito mais sentido deixar ela envolvida na causa do que na empresa e a gente acabou assumindo" (entrevistada GAG)
}

A entrevistada afirmou que essa não é a forma como os processos caminham idealmente. Mesmo assim, o fato de assumir por completo a operação do negócio chama atenção por ser único entre os entrevistados. O cuidado na seleção precisa ser grande justamente porque o investimento representa um vínculo. Porém, quando esse vínculo pode 
ser alterado e alguma parte retirada da relação, talvez não seja tão primordial avaliar antes firmar uma associação.

O fundo faz avaliações mais operacionais e financeiras. Eles já pesquisaram e procuraram implementar avaliações sociais, porém, desistiram devido às dificuldades de implementação e à observação de que parte dos negócios era vendida para fundos tradicionais, então a avaliação social não agregaria muito valor quando a GAG saísse dos negócios: "as nossas saídas provavelmente serão com fundos tradicionais, (...) o impacto para eles é importante desde que gere retorno financeiro" (entrevistada GAG). As avaliações são analisadas em reuniões mensais entre os negócios e o fundo, para as quais os negócios mandam reportes operacionais e informam outros fatos, como mudanças no time quando ocorrem. Nessas reuniões estratégicas também conversam sobre financeiro, comercial, RH e Tecnologia da Informação.

Geralmente, a GAG não mede resultados nos clientes finais dos negócios. Porém, excepcionalmente, já foram pesquisar e divulgar um serviço para possíveis clientes de um negócio. Como nos demais investidores, os negócios são responsáveis pela coleta de dados e arcam com seus custos, mas, nos casos em que era muito difícil para o negócio coletar dados financeiros, por exemplo pelo tamanho da equipe do negócio, essa atividade era feita por uma pessoa da GAG.O fundo avalia apenas aspectos operacionais e com instrumentos financeiros tradicionais, como fluxo de caixa.

Como lição aprendida da implementação da avaliação, a GAG percebeu que é importante ter reuniões mais formalizadas em que todos tenham acesso previamente aos dados que serão discutidos. Como lição do resultado de avaliação, aprenderam que é muito importante que o negócio consiga se adequar às necessidades do mercado, pois, por exemplo, em um dos negócios investidos foi necessário mudar o nicho atendido e as características do serviço. A valorização da flexibilidade do negócio também acontece na Dín4mo.

\subsubsection{MOV}

A MOV foca sua atuação em organizações que diminuam as desigualdades sociais e promovam o uso sustentável de recursos naturais. Para selecionar os negócios, o fundo avalia geração de impacto, se pode resolver um problema importante, como é o empreendedor e se o negócio está bem embasado e pode crescer, o que eles chamam de "virtuosismo econômico":

\footnotetext{
"a gente acha que não vai existir impacto, não vai existir escalabilidade se a pessoa tiver... se você não tiver um negócio que seja virtuoso, que seja positivo, que gere caixa, que atraia pessoas interessantes, que pague pessoas interessantes, que venere
} 
pessoas interessantes, então se não existir isso, o negócio não vai crescer." (Entrevistado MOV).

Para receber o investimento, o negócio precisar já estar em atuação e ter faturado pelo menos 1 milhão de reais. Com isso, o fundo investe em negócios que não estão em um estágio tão inicial e já tiveram o modelo de negócio validado pelo mercado.

Ao investir, o fundo se torna sócio dos negócios e participa ativamente da gestão. Logo após o investimento, há uma análise sobre o modelo de negócio e são feitas adaptações em conjunto com o empreendedor para que a organização alcance o crescimento previsto pela MOV. Além disso, costuma montar uma sociedade anônima (SA) e trazer uma estrutura de governança, o que pode representar uma mudança importante nas organizações que são mais informais. Apesar disso, esforça-se para não "sufocar" o empreendedor e deixa-lo se desenvolver "o máximo possível sozinho, mas sempre estando à disposição" (entrevistado MOV).

Para acompanhar os negócios investidos, a MOV define alguns indicadores de impacto cujos resultados são analisados mensalmente junto com indicadores financeiros. Uma parte das avaliações e indicadores é personalizada, além disso, usam a metodologia do GIIRS (Global Impact Investment Rating System, "um sistema com a maior base de dados de desempenho social e ambiental de empresas sociais privadas e fundos de desenvolvimento de mercados emergentes, que fornece aos seus usuários resenhas e dados abrangentes auditados de forma independente pela B Lab" (GARCIA, 2015, p.148). Pelo fato do GIIRS ser personalizado, é possível se comparar a outros usuários da base.

A MOV se envolve na definição do que será medido e depois na análise dos resultados, assim como os demais fundos pesquisados, porém, exige que os negócios façam a avaliação pelo método GIIRS. Essa exigência só foi encontrada na MOV. No momento da pesquisa, o fundo começava a buscar parceiros para avaliarem o que está mudando nos negócios e no cliente final depois do início da parceria com a MOV.

Como estabelece o uso de uma metodologia externa que tem custo de propriedade intelectual, o GIIRS, a MOV arca com esse valor. Ela também recomenda o uso da certificação B, que tem um custo associado, mas como não é obrigatório, o custo é de cada negócio. A MOV usa uma metodologia própria e o GIIRS para avaliar o próprio fundo. E, ainda, usa o GIIRS para poder conversar com outros fundos de investimento de impacto e a certificação B para apoiar o movimento. No total, a MOV usa três tipos de avaliação sobre seu próprio desempenho, uma metodologia própria, o GIIRS e a certificação B. 
O entrevistado da MOV associa a avaliação a um processo de aprendizagem contínuo, mas não registrou nenhuma lição específica que teve durante a implementação. Ele também não indicou nenhuma lição aprendida com os resultados da avaliação, ele enxerga mais valor no processo de avaliação do que nos resultados especificamente: "Eu acho que é importante as empresas se questionarem em relação ao impacto das operações que gera, então o próprio fato de você fazer um diagnóstico, se preocupar com isso, ele vai gerar algum tipo de mudança, então é importante que seja feito." (Entrevistado MOV).

\subsubsection{SITAWI}

"A SITAWI é uma organização social de interesse público (OSCIP) que mobiliza capital para impacto socioambiental positivo" (SITAWI, 2017). Os negócios sociais chegam à SITAWI pelo site, indicação de parceiros e a OSCIP os procuram ativamente também. A partir daí, há uma avaliação de diversos aspectos (impacto social e ou ambiental, capacidade de pagar o investimento de volta, equipe de gestão qualificada e liderança com fibra ética) que ocorre em várias etapas para decidir se organização deve receber investimento ou empréstimo.

A participação deste investidor na gestão do negócio é baixa. Os negócios reportam dados mensalmente. Tais dados foram combinados e estão descritos no contrato de empréstimo ou investimento, assim como no caso da Bemtevi. A diferença é que na SITAWI são definidas apenas as métricas, não metas, e isso não afeta o pagamento de juros do empréstimo tomado. A SITAWI envolve-se apenas no planejamento do que deve ser avaliado e como a avaliação deve ocorrer. A coleta de dados é responsabilidade do negócio.

As avaliações usam uma metodologia interna, porém, sob influência da proposta pela Acumen e pautada no GIIRS. Ela também usa o GIIRS para avaliar a si própria e escolheu essa metodologia para poder se comparar a outros investidores.

Ao longo do tempo, a SITAWI considerou que aprendeu quais questionamentos das avaliações seriam mais importantes para tomarem decisões futuras e aprimoraram o formulário de coleta de dados. O processo de reflexão foi baseado em feedback e tentativas e erros dos integrantes da equipe da SITAWI.

Como lição aprendida com os resultados da própria SITAWI, a organização percebeu que o foco de atuação era amplo demais e teve uma ação bem parecida com a de uma consultoria para mapear e mostrar aos investidores suas preferências de área de atuação. 


\subsubsection{Vox Capital}

A Vox Capital "investe em tecnologias inovadoras, fortalece o ecossistema de negócios de impacto e inspira as pessoas a fazerem parte dessa transformação" (VOX, 2017). Para selecionar as organizações não há um processo formal ou requisitos determinados.

O fundo torna-se sócio minoritário dos negócios e trabalha com Venture Capital, que é o investimento em negócios que estão em seu estágio inicial. A gestão é responsabilidade do empreendedor, mas há proximidade e participação da Vox.

A avaliação dos negócios é feita formalmente por meio do acompanhamento de certidões negativas nos órgãos estatais, aos quais as empresas precisam pagar tributos, também é feita informalmente por meio de conversas com o empreendedor. A Vox Capital considera, ainda, que um forte indicador de problemas de gestão são os ruídos de comunicação internamente na equipe do negócio.

Além de participar do planejamento e análise das avaliações, a Vox Capital coleta dados dos negócios diretamente, como o crescimento da base de clientes, e faz contato direto com o cliente final. Os custos da avaliação identificados pela entrevistada são de tempo do empreendedor e da equipe Vox, cada um arca com seu custo em termos de tempo aplicado às atividades. Além do custo financeiro, há uma decisão sobre o momento certo de avaliar, considerando a maturidade de cada negócio, o que também que pode tomar tempo de ambas as equipes.

Os indicadores da avaliação são alterados e aprimorados conforme as mudanças do negócio e de seu ambiente, o que é muito recorrente no ambiente de startup, para a entrevistada os negócios sociais com os quais a Vox se relaciona são empresas desse tipo. "Trabalhar com startup é uma coisa muito dinâmica, conforme você vai investindo, vai descobrindo algumas coisas vão sendo incorporadas ao processo de análise e investimento." (entrevistada Vox Capital). Não houve processo de reflexão formal para tais mudanças e melhorias.

Com os resultados de avaliações e acompanhamento dos negócios, a Vox aprendeu a dar mais importância à equipe empreendedora do que ao modelo de negócio, pois o modelo pode ser transformado, já a equipe não pode ser mudada. O processo de reflexão que levou a essa aprendizagem foi orgânico e informal devido ao tamanho reduzido da equipe da Vox Capital. 
A informalidade dos processos de avaliação é algo que a Vox Capital gostaria de mudar. Porém, a entrevistada argumenta que o setor ainda está descobrindo a questão da avaliação e ter um sistema robusto e formal não é uma prioridade no momento para o fundo.

A entrevistada indicou que há tolerância ao erro e apoio ao empreendedor quando ele acontece, o que é recomendado por Marr (2006), especialmente porque o valor do fundo depende do retorno de cada negócio. Uma vez que o investimento já aconteceu, há interesse em ajudá-lo a superar o problema e ganhar valor.

\subsubsection{Comparação entre investidores}

A partir da exposição das características dos investidores será realizada uma comparação entre eles do ponto de vista dos assuntos indicados nos objetivos específicos, ou seja, caracterização das organizações e avaliações, indicação das lições aprendidas a partir das avaliações quando existem e barreiras e dificuldades de avaliar. A base para análise exposta nesse tópico parte das evidências encontradas nas entrevistas e documentos.

O processo de seleção dos negócios e investimento costuma ter mais de uma etapa para dar ao investidor insumos para a decisão de investir ou emprestar capital financeiro, como e quando. Boa parte desse processo foi subjetiva e não se apoiou em indicadores ou testes formais. Uma das razões disso pode ter sido o pouco tempo de existência do setor, o que explicaria processos pouco desenvolvidos. Os investidores, especialmente os fundos Vox e GAG, são criteriosos ao avaliar o empreendedor por trás do negócio e consideram esse um fator decisivo para o investimento.

A forma como os investidores aplicam o dinheiro e sua participação na gestão variou bastante entre os entrevistados. A maior parte acompanha mensalmente os resultados financeiros e alguns indicadores sociais dos negócios. O foco do apoio em gestão dado aos negócios costuma ser mais estratégico do que operacional. A Dín4amo apoia a gestão mais que os outros investidores enquanto o negócio está em seu processo de aceleração, depois espera que os empreendedores forneçam reportes trimestrais e apresenta pouca participação na gestão. A SITAWI também apresenta pouca participação na gestão uma vez que o recurso financeiro é aplicado.

Por outro lado, o fundo GAG não investe em negócios em que não possa participar da gestão, pois acredita que há uma carência de capital humano nos negócios. A MOV também exerce uma participação muito ativa na gestão, costuma reformular a estrutura de governança da empresa, dá recomendações estratégicas e pode alterar parte da equipe do negócio. A 
autonomia de negócios investidos pela MOV em alguns aspectos é subordinada a um conselho consultivo. A GAG e a MOV são os fundos mais presentes na gestão. Pelos relatos encontrados e a comparação entre os casos, os investidores mais presentes na gestão também são os mais participativos nas atividades de avaliação.

As avaliações mais comuns são as também presentes em negócios tradicionais, tais como financeiras e operacionais. Ou seja, ainda não há uma necessidade de os negócios avaliarem seu desempenho em aspectos da atuação social, o que geraria diversas particularidades para a avaliação desses negócios. É possível que quando o campo estiver mais desenvolvido, haja uma exigência de avaliações e resultados sociais mais conclusivos.

A participação dos investidores na avaliação se concentra no planejamento e definição junto aos negócios de quais indicadores serão acompanhados. A coleta de dados costuma ser responsabilidade do negócio. Bemtevi e SITAWI colocam no contrato de empréstimo quais são as métricas acordadas entre o investidor e o negócio. Em alguns casos, e de maneira informal, os fundos pesquisam o cliente final do negócio. A MOV exige que os negócios investidos façam a avaliação pelo método GIIRS.

Para compreender melhor as questões em torno da avaliação, é interessante verificar os recursos necessários para que ela aconteça. Os recursos dos negócios sociais tais como mão de obra e tempo são bastante limitados devido ao tamanho reduzido de suas equipes. Há um custo de tempo em planejamento, coleta e análise dos dados para a avaliação. As horas gastas em planejamento e análises, como são feitos em conjunto entre investidor e negócio, geram um custo absorvido por ambos. O custo da coleta de dados fica com o negócio, porém, nos casos da SITAWI e Vox há uma preocupação em solicitar dados que sejam de interesse do negócio e que não sejam de difícil coleta.

O entrevistado da Dín4mo considera que há dificuldade tanto para o negócio quanto para o investidor pagar por uma avaliação externa, pois as avalições mais relevantes para a atuação de negócios sociais ainda são muito caras. Ele acredita que a resposta para essa questão virá com o amadurecimento do mercado. A MOV arca com o custo de direito da metodologia GIIRS.

Com exceção da MOV, os investidores usam apenas metodologias de avaliação internas. A MOV usa uma metodologia própria e o GIIRS tanto para o fundo quanto para cada negócio. Ela também recomenda a certificação $\mathrm{B}$, mas não é uma avaliação obrigatória. $\mathrm{A}$ SITAWI usa metodologia interna adequada aos critérios da metodologia GIIRS e Acumen. SITAWI e MOV usam, em parte, o GIIRS para poderem se comparar a outros fundos. A 
Dín4mo tem a certificação B na sua organização, mas não exige isso dos negócios. MOV e Dín4mo usam certificação B para reforçar o movimento.

A maior parte dos entrevistados reconhece e identifica momentos de aprendizagem que ocorreram na implementação da avaliação. Os aprendizados e mudanças que derivam deles não acontecem por meio de processos formais de reflexão. A melhor forma de avaliar é descoberta por tentativas e erros e também por feedback dos que precisam das avaliações para tomar decisões. É provável que o caráter informal se deva ao tamanho das equipes das organizações investidoras que, na maior parte dos casos pesquisados, contavam com menos de dez pessoas.

Marr (2006) analisa o ambiente de aprendizagem e faz diversas sugestões sobre as reuniões em que participam apenas gestores de nível hierárquico mais alto, tais como focar no planejamento de melhorias para o futuro e não em responsabilização por erros do passado. No caso dos fundos de investimento pesquisados, é comum que toda a equipe da organização participe das reuniões de análise e reflexão sobre os resultados.

Nesse aspecto se destaca a Bemtevi, que no momento da entrevista tinha apenas um caso de empréstimo feito e descreveu aprendizados de ações positivas mais do que de erros. A Dín4mo não reconheceu nenhum aprendizado sobre implementação, pois alega que já domina as técnicas que usa e, por isso, há pouco espaço para aprender. A MOV não identificou nenhum aprendizado em específico, mas reconhece o que o maior valor da avaliação está, de fato, em sua recorrência e no ciclo de aprendizado que ela representa.

Outro ponto de interesse da pesquisa era o aprendizado em relação aos resultados da avaliação. A Bemtevi emprestou capital financeiro para seu primeiro negócio parceiro muito recentemente e ainda não teve a primeira rodada de avaliação, nem tinha recebido os primeiros resultados da avaliação do negócio no momento da entrevista. A Dín4mo comentou que, por lidar com negócios de diferentes perfis e setores, o que aprendeu com o resultado da avaliação de um negócio dificilmente se aplicaria a outro.

A GAG aprendeu com os resultados da avaliação feita pelo mercado, a que acontece quando um serviço ou produto ou serviço é colocado à venda e pode-se interpretar sua recepção pelos clientes como resultado de sua adequação ou falta dela ao público a que foi exposto. A GAG ajudou um negócio a mudar seu público-alvo por descobrir que não havia demanda no primeiro nicho proposto. A SITAWI já aprendeu com resultados de avaliações internas: uma das lições aprendidas foi que o foco ambiental e social sem nenhuma especificação era amplo demais e restringiram a atuação para alguns setores. 
A maior parte dos fundos de investimento entrevistada disse ser tolerante aos erros tanto internos quanto dos negócios investidos. O erro é visto com fonte de inovação "faz parte do caráter inovador da organização, senão você não conseguiria inovar se você não pode testar e errar." (entrevistada SITAWI) e de aprendizagem "para mim, erro é matéria prima" (entrevistado Dín4mo). Há uma preocupação em identificar erro o mais rápido possível e corrigir.

A Bemtevi informou que ficaria preocupada se o erro fosse causado não por estimativa errada, mas por displicência do negócio. GAG e Vox alegaram uma postura de apoio em vez de punição aos negócios quando erram. Isso pode acontecer, pois há uma grande intenção e expectativa que os negócios investidos se desenvolvam e parte do valor dos fundos depende do valor dos negócios investidos.

Pelas entrevistas, somadas aos relatos de todos os investidores, é possível afirmar que houve muitos aprendizados, devido ao ambiente que tolera erros e favorece inovação em que os negócios sociais e investidores estão. Porém, poucos deles deveram-se aos processos de avaliação, que na maior parte dos casos ainda são informais e não prioritários frente a outras atividades de gestão.

\subsection{Negócios Sociais}

\subsubsection{Descrição dos negócios sociais}

Neste tópico serão apresentados os negócios sociais pesquisados nos casos. Também serão descritas as características das organizações, suas missões, ações e o que se destacou na análise de seus dados em relação às outras organizações do mesmo tipo. A partir daí, serão expostas as características dos métodos de avaliação, quais foram as lições aprendidas com a avaliação e quais são as dificuldades em se avaliar.

\subsubsection{CIES}

CIES é a sigla para Centro de Integração de Educação e Saúde, o negócio social do ramo de saúde cuja missão é "Atender a necessidade de saúde integral do ser humano com qualidade, tecnologia e agilidade no conceito de tratar, educar e prevenir" (CIES, 2017). Eles fazem isso por meio da realização de exames médicos de baixa e média complexidade em carretas que vão até às populações que têm menos acesso à saúde. 
De acordo com a entrevistada, a maior parte dos contratos de serviço do CIES é com o poder público que realiza atendimentos pelo Sistema Único de Saúde - SUS ${ }^{2}$, cuja maioria dos usuários pertence à baixa renda (SILVA; RIBEIRO; BARATA; ALMEIDA, 2011). Fora isso, não há uma especificação de nicho de atuação, a região geográfica a ser atendida é determinada pelo órgão público contratante, que costuma ser a prefeitura do local. A população de baixa renda é beneficiada com acesso gratuito a exames médicos nas regiões periféricas das cidades. A parceria com o poder público exige uma prestação de contas que gera necessidade de um acompanhamento dos resultados, que é um tipo de avaliação formal.

No momento da entrevista, o negócio já conseguia manter suas atividades sem investimentos financeiros externos. O CIES usava naquele momento o empréstimo da SITAWI apenas para novos projetos que requeriam investimento de maior volume. Eles já usaram empréstimos da SITAWI mais de uma vez e devem usar novamente se houver necessidade de crescimento. A entrevistada não soube especificar os requisitos necessários, porém, ela manda relatórios mensalmente para a SITAWI, que são requeridos em contrapartida ao investimento. Por isso, ela foi a pessoa recomendada pela SITAWI a ser entrevistada.

Os processos de avaliação utilizados no CIES foram desenvolvidos internamente. Os aspectos avaliados são financeiros, operacionais e sociais, como a organização é grande, há mais de um responsável pela avaliação. A iniciativa de formalizar uma avaliação foi do negócio, mas a entrevistada reconhece que o pedido da SITAWI gera uma aceleração no desenvolvimento do processo. O CIES avalia para melhorar gestão e satisfazer pacientes. Porém, o dado que mais se preocupam em avaliar é mais usado para a divulgação e prestação de contas para o órgão contratante do que para melhorias internas.

A entrevistada enxerga um custo de uso de recursos no processo de avaliação, com o qual o CIES arca. A organização não pesquisou nenhum parceiro que estivesse disposto a pagar. O acompanhamento dos resultados é uma atividade constante na organização, mas não acontece de maneira formalizada.

Um aprendizado em relação à implementação da avaliação é que o tempo de fila de espera para exames médicos varia muito durante o mês, então o ideal é coletar esse dado no dia em que a agenda de exames é aberta na prefeitura que contratou. O CIES aprendeu,

${ }^{2}$ O SUS é o Sistema Único de Saúde, que oferece a todo cidadão brasileiro acesso integral, universal e gratuito a serviços de saúde. O Sistema beneficia cerca de 180 milhões de brasileiros, sendo o único acesso à saúde para maior parte da população. Ele enfrenta diversos desafios tais como a gestão do sistema e também no subfinancimento da saúde (falta de recursos) (FUNDAÇÃO OSWALDO CRUZ, 2017) 
também, que os dados são mais facilmente coletados nas regiões em que há mais funcionários da prefeitura em questão. Porém, esse é um aprendizado que não se concretiza em uma mudança efetiva porque o CIES não consegue alterar o número de funcionários da prefeitura. O alcance do aprendizado é parcial já que a decisão gerencial não está a seu alcance. Ou seja, não é possível implementar mudanças nesse sentido.

O CIES aprende com frequência com os resultados das avaliações. Ele não faz uma pesquisa formal de satisfação do cliente, mas sempre há alguém do CIES em contato com os pacientes, perguntando sobre o que deveria ser modificado. Já mudaram muitos aspectos e processos com base nisso. Além dos melhoramentos feitos a partir de avaliação, outra forma de aprimoramento dos processos se dá por observação, o CIES já mudou o fluxo do serviço nas carretas, alguns pacientes perdiam suas fichas de atendimento e o CIES passou a entregar o documento só no final do atendimento, por exemplo.

Outras melhorias de gestão surgem por nova demanda e ideia dos funcionários, tais como: aumentar os horários em que é possível fazer exame médico que precisa de jejum do paciente. Outras mudanças acontecem a pedido de funcionários da atividade, como médicos e enfermeiros. O horário de um exame que requer mais atenção foi mudado para uma hora em que o médico está mais descansado, por exemplo.

A entrevista identifica barreiras na avaliação, como dificuldades de acesso aos dados e não isolamento da atuação do CIES (há diversos parceiros do SUS que também fazem exames, o tempo de fila de espera pode aumentar ou diminuir independentemente do CIES).

Quanto ao não cumprimento de metas e erros, que são tidos nessa pesquisa como fenômenos da mesma natureza, o CIES informa que acorda metas de números de atendimentos com o governo municipal e às vezes não conseguem atingir por baixa demanda de paciente, ou porque os pacientes agendam o exame, mas não comparecem, por exemplo. Nesse caso, o CIES abre mais vagas desse exame, conversa com o governo e certifica-se que a demanda e os agendamentos estejam corretos. A entrevistada relata que há uma grande pressão para alcançarem as metas. Isto contrasta com o que foi dito pelo seu investidor, SITAWI em relação à tolerância aos erros. Porém, pode acontecer porque a fonte de pressão pode ser o cliente, que no caso é o governo, devido à prestação de contas com esse ente, o que está fora do alcance ou competência da SITAWI.

\subsubsection{GlicOnline}

O GlicOnline é uma organização que atua na saúde ao operar um aplicativo que auxilia a pessoa com diabetes a acompanhar todo o tratamento da doença "através de diversas 
funcionalidades como consulta e registro de carboidratos, cálculo de dose de insulina, lembretes de medicamentos e registro de glicemia" (GLICONLINE, 2017).

O entrevistado não soube informar quantos usuários do aplicativo pertencem à base da pirâmide de renda. Como a organização lida com um nicho específico, pessoas com diabetes, a renda não faz muita diferença em como as pessoas lidam e tratam a doença de acordo com ele.

O aplicativo conta com cerca de 20 mil usuários. O entrevistado sugeriu uma aproximação da faixa de renda na qual os usuários se encontram a partir do tipo de sistema operacional do celular que eles usam. O aplicativo é usado em celulares do tipo smartphone, que contam principalmente com o sistema operacional Android ou IOS. As pessoas que possuem celulares com o sistema Android costumam ter renda mais baixa do que os que usam o sistema IOS. O GlicOnline sabe que a $80 \%$ dos usuários usam o sistema Android e 10\%, IOS.

As pessoas de baixa renda são beneficiadas pela possibilidade de um acompanhamento maior da diabetes e pela possibilidade de variar a dieta e saber quanta insulina precisa tomar, esse benefício deve ser sentido com mais intensidade pelas classes baixas, porque alguns médicos do SUS não ensinam a contagem de carboidrato ${ }^{3}$.

O negócio ainda não consegue manter suas atividades sem investimento financeiro externo, mas os gestores estão procurando formas de monetizar o aplicativo, ou seja, gerar recursos financeiros individualmente. Há pelo menos três ideias para esse propósito e as parcerias para que elas se concretizem já estão em negociação ou andamento. Uma das premissas é que a pessoa com diabetes não deve pagar para usar o aplicativo. O entrevistado percebe que talvez o negócio sempre tenha um investidor externo, dado que o fundo que investiu na GlicOnline pretende vender sua participação para outro fundo de investimento no futuro.

Pesa no relato da organização, o fato de que os empreendedores originais não estão mais à frente do negócio, como foi explicado no tópico sobre o fundo GAG. O entrevistado não soube responder o que foi necessário para receber o investimento porque não estava na

\footnotetext{
${ }^{3}$ Muitas pessoas com diabetes precisam tomar insulina a cada refeição para regular os níveis de açúcar no sangue. A quantidade de insulina a ser administrada varia de acordo com o paciente e com a quantidade de carboidrato em cada refeição. Para saber quanta insulina tomar, é necessário identificar a quantidade de carboidrato em cada alimento ingerido, o que é chamado de contagem de carboidrato.
} 
equipe nessa época. É provável que essa ruptura de gestão tenha afetado negativamente a linha de conhecimento e reflexão, especialmente porque não houve um período em que os empreendedores originais e os atuais tenham trabalhado juntos.

O negócio utiliza métodos formais e tradicionais de avaliação como fluxo de caixa, número de usuários e dados sobre os usuários. No próprio aplicativo, o usuário responde como está seu humor no dia (não necessariamente em relação à doença), o que pode ser considerado uma avaliação sua em relação ao seu tratamento, uma vez que a doença é um aspecto importante da vida de quem tem diabetes. O entrevistado informou que os usuários que usam o aplicativo há mais tempo tendem a ter um humor melhor. Para aumentar o contato com o usuário, há uma central de atendimento telefônica que recebe reclamações, elogios e sugestões de clientes e médicos, o que também é um tipo de monitoramento. A partir desse contato já identificaram problemas no aplicativo e oportunidades de parceria com uma empresa farmacêutica.

Os processos de avaliação foram uma demanda do investidor. Quando os gestores atuais começaram a operar o negócio, esses procedimentos já estavam iniciados. A análise dos dados coletados acontece em reuniões com uma frequência entre duas semanas e um mês e o investidor está presente.

O negócio teve dois aprendizados com a implementação da avaliação. O primeiro foi mudar o que consideram usuário ativo, porque se considerarem que é apenas uma pessoa com o aplicativo no celular, mas que não o utiliza, não há muita relevância para a base de dados que construíram. O segundo aprendizado foi rever como contar os usuários, porque na forma original poderia haver duplicidade.

O GlicOnline também acompanha as sugestões dos usuários em canais virtuais como o GooglePlay, em que os usuários podem avaliar o aplicativo e, no momento de troca de gestão, algumas pessoas chave com diabetes foram convidadas para uma reunião de avaliação do produto. A partir dos resultados das avaliações dos usuários vindas tanto a partir do GooglePlay quanto da reunião descrita, o GlicOnline mudou alguns aspectos e possibilidades do aplicativo.

A busca ativa por críticas e sugestões pode ser consequência de o produto não ser resultado do trabalho dos gestores atuais e sim dos sócios-fundadores. Isso talvez ajude a estarem abertos a críticas, pois há um maior distanciamento em relação aos fundadores, o que pode dar mais liberdade de atuação aos novos gestores.

Além das mudanças ocorridas a partir das lições aprendidas por meio das avaliações, outra forma de aprimoramento de processos internos consiste em comunicação constante dos 
gestores com a equipe de tecnologia. Os gestores procuram ter controle do que acontece e informar aos funcionários sobre um panorama geral do negócio. De acordo com o entrevistado, isso é bom para que a equipe de tecnologia fique mais tranquila sobre o rumo do negócio e seu emprego e, assim, os gestores sabem sobre a rotina e onde há dúvidas e dificuldades.

Outra oportunidade de aprendizado aconteceu quando o negócio cometeu um erro importante. O GlicOnline lançou uma versão do aplicativo que fez com que todos os usuários ficassem sem o serviço em seus celulares. A equipe do GlicOnline trabalhou ininterruptamente até que o problema fosse resolvido. A partir disso, criaram uma rotina melhor de testes de tecnologia. Essa experiência também mostrou a importância do serviço para o usuário. Uma usuária grávida ligou para o negócio informando que precisaria que o serviço fosse restaurado com urgência para saber quanta insulina usar em suas refeições no dia seguinte.

Uma dificuldade identificada na avaliação é o fato de não conseguirem comparar a saúde dos usuários antes e depois do uso do aplicativo. O negócio está desenvolvendo uma forma de importação do histórico do paciente para facilitar a análise do antes e depois, o que deve ajudar a resolver essa questão e a mostrar para os possíveis clientes os dados agregados, tais como planos de saúde e as mudanças e melhorias causadas na saúde dos usuários do aplicativo.

\subsubsection{PanoSocial}

A PanoSocial é uma empresa do ramo têxtil que confecciona eco-bags, camisetas e outros artigos para sua grife e outras marcas sempre com algodão 100\% orgânico ou com PET $100 \%$ reciclado. Na sua atuação, capacita egressos do sistema prisional e os inclui em sua cadeia de produção. A maior parte do público beneficiado por sua intervenção, que nesse caso se insere como mão-de-obra da cadeia produtiva do negócio social e não como clientes, situação prevista por Yunus e Weber (2007), tem baixa renda e pertence a um nicho específico, o de ex-detentos.

O negócio ainda não consegue manter suas atividades sem investimento externo, a PanoSocial começou a operar no modelo atual há menos de um ano. Mas há um planejamento para isso. Como foi feito um empréstimo, a ideia é pagar e gerir o negócio individualmente.

Para ter acesso ao empréstimo, foi necessário elaborar um planejamento de como o dinheiro seria gerido uma vez que estivesse no negócio e como seria devolvido, em que condições. Este plano precisou ser aprovado pelos gestores da organização Bemtevi (que 
concedeu o empréstimo) e encaminhado e assinado pelo seu conselho. O processo durou mais do que o previsto e a PanoSocial precisou iniciar suas atividades antes mesmo do empréstimo da Bemtevi.

O método de avaliação foi desenvolvido pela organização por exigência do investidor e com forte participação e apoio deles e de parceiros, tais como pesquisadoras acadêmicas, ao longo de vários meses. Como era o primeiro empréstimo da Bemtevi, houve uma preocupação em criar um plano bastante detalhado que servisse de exemplo para os próximos casos.

O método de avaliação contém aspectos ambientais (tais como pegada de carbono e uso de água no cultivo e transporte das matérias-primas), financeiros (número de vendas, fluxo de caixa, percentual de pagamento do empréstimo) e sociais (como horas gastas em capacitação dos egressos do sistema prisional, atendimento psicológico, inclusão no mercado de trabalho fora ou dentro da PanoSocial, entre outros).

Além dessa avaliação em nível mais estratégico, a organização monitora em um nível mais operacional, um exemplo é o monitoramento da linha de produção. A implementação disso foi feita por uma funcionária que já trabalhava no setor de produção em outra empresa da indústria têxtil, pois os gestores da PanoSocial não possuem experiência prévia com confecção ou indústria têxtil. Os entrevistados afirmam que devem cronometrar as etapas da produção para descobrirem como podem acelerar sem causar desconforto aos funcionários. Ademais, receberam um feedback espontâneo da esposa de um funcionário sobre sua melhora de comportamento, que também é uma forma de avaliação que não havia sido buscada ativamente.

A PanoSocial reconhece que houve um custo de tempo no planejamento da avaliação e que há um custo na coleta de dados. Como o negócio é novo, os empreendedores ainda não sabem quanto tempo as atividades de coleta de dados demandam. Mesmo se consumir muito tempo, eles estão interessados em investi-lo pela importância da atividade.

Também por terem iniciado o negócio recentemente, ainda não identificaram lições aprendidas na implementação das avaliações ou em seus resultados e nem mudanças que elas pudessem ter gerado. Nesse momento, eles se preocupam em deixar os processos mais organizados para posteriormente coletarem dados e poderem analisá-los com calma e propriedade. Porém, o exercício de planejar avaliação e metas já gerou ideias sobre o negócio e seu possível alcance antes dele estar ativo. Por enquanto, a maior dificuldade de avaliação é identificar valores de como cada recurso compõem o custo final do produto, o que parece adequado ao estágio em que o negócio está. 
Mesmo ainda sem medir formalmente os resultados, a PanoSocial foi considerada importante para essa pesquisa, pois houve um trabalho de mais de um ano em conjunto com o investidor para criar metas e como medi-las, em que a pesquisadora participou como consultora voluntária, o que deu acesso a informações sobre o caso e seu desenvolvimento. Havia indícios de que a organização fazia avaliação, mas eles não se confirmaram e, mesmo assim, o caso foi mantido entre os selecionados pelo planejamento que a empresa já tem de como pretende fazer as avaliações.

Há uma percepção por parte da PanoSocial de que alguns erros podem afetar o desenvolvimento e falir o negócio, mas também de que eles são importantes para gerar aprendizagem.

\subsubsection{Tem}

A Tem é um negócio do ramo de finanças e saúde. Ele opera "para promover acesso a serviços médicos qualificados e com preços reduzidos” (TEM, 2017). A ideia do negócio é oferecer um cartão pré ou pós-pago em que as pessoas possam guardar dinheiro para gastarem apenas com saúde, quando necessário, por meio do pagamento de consultas médicas e medicamentos.

Sobre o percentual de clientes que pertence à base da pirâmide, não há um dado específico sobre a renda dos usuários, mas há uma medida aproximada desse dado considerando a distribuição de venda dos cartões que ocorrem principalmente em lojas de varejo parceiras voltadas para as classes mais baixas. A Tem conta com cerca de 23 mil usuários que se beneficiam com descontos em serviços médicos e medicamentos de uma ampla rede de prestadores de serviços e produtos em saúde em localidades e especialidades diferentes.

O negócio ainda não consegue manter suas atividades sem investimento externo, mas planeja alcançar o momento de ponto de equilíbrio o mais rápido possível e já tomou ações em relação a isso, como "uma enxugada na nossa estrutura de custos" (entrevistada Tem).

Para ter acesso ao investimento da Vox, foi necessário apresentar a tese de mudança que o negócio busca. De acordo com a entrevistada, isso foi até mais importante do que o número de usuários, que é um indicador mais operacional. Pela relevância que a Vox parece dar para o aspecto social, o negócio desenvolve os indicadores de impacto. Há uma oportunidade de aprendizado conjunto entre negócio e investidor.

O negócio avalia sua atuação formalmente por meio de uma grande planilha apresentada à pesquisadora com aspectos sociais e operacionais. Além disso, há uma pesquisa 
de satisfação feita com os usuários depois que eles usam um serviço de consulta médica e uma investigação do preço da consulta particular dos médicos, que flutua muito e é usada para identificar o percentual de desconto dado pela Tem em relação ao preço tradicional da consulta. O método de avaliação foi desenvolvido pela própria empresa com participação de toda a equipe, pois é um grupo pequeno. O contato com a Vox sobre a avaliação acontece principalmente para reportar os resultados encontrados. A Vox interfere na gestão para que o negócio chegue ao melhor modelo de negócio.

A entrevistada da Tem afirma lições aprendidas na implementação da avaliação, especialmente na escolha de quais indicadores devem ser pesquisados. Em um primeiro momento, o grupo gostaria de medir a resolutividade dos casos, ou seja, o percentual que pessoas que se curou depois de ter feito uma consulta comparando com todos os que fizeram uma consulta. Porém, viram que não seria possível auferir esse dado por questões de sigilo médico, então começaram a acompanhar a satisfação dos pacientes em relação ao serviço e tratamento que receberam. Além disso, no momento de planejamento e implementação, é possível identificar quais dados são mais relevantes para o negócio e devem receber mais esforço de pesquisa.

Com os resultados da avaliação, também houve lições aprendidas. Descobriu-se que há uma grande procura pelas especialidades oftalmologia e dermatologia, o que foi uma surpresa para os gestores. Com isso, entenderam que o comportamento de quem acaba de aderir ao cartão é buscar aquilo que mais gostaria, mas tem dificuldade de conseguir pelo sistema público, e não necessariamente o que é mais urgente.

Há outras lições aprendidas ao longo da trajetória da Tem sem relação com avaliação. A primeira delas é que a mensalidade é uma barreira de entrada para a compra do produto. Por isso, estão desenvolvendo outro produto que não tem essa barreira. $\mathrm{O}$ primeiro não deixará de existir por causa disso.

A entrevistada comentou que, por acidente, uma pessoa de baixa renda do círculo de convivência dos empreendedores foi deixada com um cartão e uma instrução escrita, mas sem uma explicação mais detalhada. Essa pessoa entendeu como funcionava o serviço e fez o uso, mas teve um problema em relação ao crédito necessário para fazer uma consulta médica. Com isso, o negócio aprendeu que sua instrução estava clara o suficiente para o público-alvo, mas havia um problema de prazo de pagamento. A partir disso, foi instituído um processo de confirmação de crédito que precede à marcação de consulta e a equipe do negócio começou a pensar em uma forma de facilitar o pagamento, o que é um tido como um desafio até hoje. 
Outro desafio atrelado à gestão foi a forma como o vendedor do cartão coleta os dados dos clientes para inserir no sistema. Inicialmente, esses dados vinham com muitos erros ou ausências, o que impedia o contato da Tem com o cliente. Na tentativa de resolver esse problema, foi criada uma comissão sobre venda dos cartões. Porém, a empresa aprendeu que há muitas fraudes nesse método, então a comissão foi cancelada. $\mathrm{O}$ primeiro contato com o cliente continua um problema. A Tem é um dos negócios selecionados que mais relatou aprendizados.

Sobre os erros, a entrevistada comentou que já sabem como fazer uma meta alcançável, então erros desse tipo raramente acontecem. Ela relatou a tentativa que fizeram de uma parceria com um outro negócio apoiado pela Vox e que não alcançou o resultado esperado. A ideia era oferecer o cartão para os clientes de um negócio que tem como missão oferecer serviços bancários para a baixa renda, porém, os clientes do negócio parceiro não pagavam a mensalidade, por isso, não tinham como usar o serviço da Tem. Ela também comentou que não há uma condenação dos que cometeram erros, mas é muito importante ficar atento às falhas, porque algumas delas podem inviabilizar o negócio.

A entrevistada enxerga uma barreira na avaliação referente ao custo de desenvolvimento de uma tecnologia que consiga coletar dados de forma eficiente, para que a avaliação entrasse na rotina do negócio. Não ficou claro se o investimento nessa tecnologia seria feito pelo negócio ou investidor.

\subsubsection{Triciclos}

A Triciclos é um negócio do setor de gestão de resíduos sólidos que busca a “construção de hábitos mais sustentáveis na sociedade” (TRICICLOS, 2017). Ela faz isso por meio de ferramentas como logística reversa, prestação de serviço por cooperativas de catadores, assessorias e diagnósticos e programas de educação ambiental. "A grande missão da Triciclos é transformar uma economia linear em circular" (entrevistada Triciclos).

A entrevistada informou que há principalmente dois focos de atuação, um ambiental, de conscientização da sociedade sobre o lixo que produz e como o "consumo afeta o meio ambiente" e outro mais social em parceria com cooperativas de catadores de materiais recicláveis. Parte do trabalho da Triciclos consiste em recolher o lixo nos pontos de entrega voluntário, em que uma pessoa de uma cooperativa orienta sobre como os resíduos devem ser entregues. Há uma preocupação em "profissionalizar, [...] comparar a qualidade do material anterior com a qualidade do material depois que a gente (Triciclos) faz a mudança de cultura, então como isso agrega valor ao material que eles (as cooperativas) vendem, como que a 
gente consegue $[\ldots]$ tornar as cooperativas prestadoras de serviço.” (entrevistada Triciclos). A população de baixa renda representada nesse caso é beneficiada com a inserção na cadeia produtiva, são cerca de 2 mil cooperados parceiros.

A organização já consegue se manter sem investimento externo, mas gostaria de crescer mais e estuda se isso deve ser feito mais rapidamente, com investimento externo, ou em ritmo mais lento, de forma mais individual e independente. A MOV é o fundo que investe na Triciclos, sendo que nesse caso, o investidor buscou o negócio. Antes do investimento, foi feita uma grande avaliação da Triciclos, que durou cerca de dois anos e teve como etapa o GIIRS. O negócio continua avaliando seu desempenho pelo GIIRS e pela Certificação B, que são dois métodos externos. A certificação B é recomendada, mas não exigida pelo fundo.

Depois que os resultados são aferidos, há uma análise junto com o investidor, fundadores da Triciclos e duas pessoas externas que buscam oportunidades de melhoria e planos de ação que devem ser seguidos nos próximos dois anos, que constituem o ciclo de avaliação. As metas propostas a partir da análise dessas avaliações são revistas mensalmente.

A entrevistada enxerga um custo no processo de avaliação tanto de uso das propriedades das marcas das avaliações quanto de horas trabalhadas da equipe. O custo de uso de propriedade do GIIRS fica com o investidor e o negócio arca com os custos da Certificação B. A entrevistada afirma que mesmo em uma crise financeira continuariam fazendo essas avaliações, pois dependem delas para mostrar e melhorar o resultado.

Uma lição aprendida com a implementação da avaliação é a importância de toda a equipe se apropriar dela. Recentemente, foi desenvolvida uma dinâmica da apresentação dos resultados da Certificação B. Há uma dificuldade percebida em motivar a equipe para apoiar a avaliação, que será abordada no parágrafo sobre esse tema mais adiante.

As lições aprendidas com os resultados são sugeridas pelo próprio sistema de avaliação. Tais lições aprendidas geram desafios que todas as empresas B são incentivadas a realizar. As lições aprendidas são coletivas nesse caso. Com esse insumo, o conselho da Triciclos define metas para o próximo ciclo de avaliação. O desafio do ciclo de avaliação atual é aumentar a diversidade na equipe da organização.

Quanto aos erros, a entrevistada apontou que sempre atingem as metas pelo menos em parte, porque separam em atividades menores e conseguem acompanhar com atenção ao longo do tempo. Quando são identificadas dificuldades em alcançar uma meta, há uma apresentação para o conselho mostrando o que foi feito, a razão por que não alcançaram o resultado pretendido e o questionamento sobre uma possível correção. 
Quanto aos obstáculos da avaliação, a entrevistada relata a dificuldade em criar o hábito na equipe de controlar e refletir sobre os procedimentos executados e depois, de comunicarem o que foi encontrado. Há uma dificuldade em motivar as pessoas a falarem e pensarem sobre o que deu errado e o que pode ser feito para melhorar. A entrevistada enxerga uma grande importância nessas atividades: "é superimportante o momento da dinâmica de sentar com as pessoas e falar o que aconteceu, por que aconteceu, como a gente pode melhorar e dar direcionamento mesmo" (entrevistada Triciclos). Ela acredita que isso aconteça por falta de tempo e porque, para algumas pessoas, a avaliação parece ser feita apenas por exigência do investidor, sem gerar maiores ganhos para o negócio. A entrevistada aprendeu com a reflexão sobre esse problema e já implementou dinâmicas para superá-lo.

\subsubsection{Vivenda}

A Vivenda é um negócio do ramo de habitação e moradia. Eles vendem o planejamento e execução de pequenas obras nas casas das pessoas de baixa renda de forma prática, rápida e com o pagamento parcelado. A base da pirâmide é beneficiada pela possibilidade de pagar parceladamente o planejamento e execução de uma reforma em sua casa.

O entrevistado acredita que todo ou quase todo o público atendido é da base da pirâmide pela localização das lojas e de um questionário econômico que fazem. Ele também comenta que em alguns casos, os clientes têm uma renda familiar maior do que seria atribuída à base da pirâmide, mas estão em uma situação de grande vulnerabilidade de moradia. Ele acredita que isso acontece porque essas pessoas não têm referência de boas condições de moradia. Ao ter mais renda, elas ampliam as casas em que moram, mas sem estrutura e planejamento. Há também um nicho específico com o qual a Vivenda trabalha por meio de uma parceria com instituições filantrópicas e o governo, atendendo as famílias em situação de vulnerabilidade extrema.

Sobre a sustentabilidade financeira, se o foco for a loja que vende as reformas, ela já opera por conta própria, sem precisar de investimento externo. Porém, o negócio como um todo ainda não chegou ao ponto de equilíbrio financeiro, especialmente porque recebem o pagamento dos clientes em até 15 vezes, mas precisam pagar os recursos de uma só vez e no início do projeto.

O entrevistado ressaltou que alcançar o ponto de equilíbrio é diferente de receber ou não investimento, pois há organizações que já são financeiramente sustentáveis, mas contam 
com investimentos externos para expansão. "A resposta (sobre ter alcançado a sustentabilidade financeira) não é tão simples assim, a gente vai fazer uma outra rodada de investimento agora, porque a gente está abrindo a segunda loja na zona leste e assim vai." (entrevistado Vivenda).

O negócio conta com o investimento de um grupo de pessoas físicas e jurídicas reunido por meio da organização Broota, como explicado no tópico sobre a Dín4mo, que liderou o movimento de aporte de capital. Os investidores, individualmente, podem optar por permanecer como sócios ou sair como se o investimento fosse apenas um empréstimo em determinados momentos pré-definidos. A participação desses investidores na gestão é menor do que quando o negócio era acelerado pela Dín4mo. Os investidores recebem informes trimestrais de indicadores definidos no momento do investimento. Quatro vezes por ano os mesmos dados são apresentados ao conselho da Vivenda, que debate o andamento do negócio.

A avaliação formal feita na Vivenda usa um método interno, ou seja, sem propriedade de outra marca, porém, com indicadores bastante tradicionais, como o número de vendas. $\mathrm{O}$ negócio também passou a monitorar os preços dos materiais que usa nas obras e comparar com os valores a que tinham comprado esses mesmos materiais, ao perceber que isso era importante para a eficiência do negócio. Mais recentemente, o negócio teve seu aspecto social avaliado por um ator externo, a Plano CDE, que também foi pesquisada neste trabalho e deve evoluir nesse sentido com uma pesquisa conduzida em parceria com a Fundação Getúlio Vargas de São Paulo.

A iniciativa de avaliar partiu do próprio negócio, porque os gestores enxergam que os itens avaliados hoje são o esforço mínimo de acompanhamento para gestão "Se uma empresa não tem indicador de gestão, ela vai quebrar mês que vem, certo?” (entrevistado Vivenda).

Os custos, o planejamento, a coleta de dados e a apresentação são feitos pelo negócio, que arca com eles. No caso das avaliações sociais externas, a feita pela Plano CDE foi paga por um parceiro e a feita pela FGV ocorreu porque um professor dessa instituição é do conselho da Vivenda. A Vivenda não pagou por essas avaliações externas.

O entrevistado não associou nenhuma lição aprendida à implementação ou resultados da avaliação, porém comentou que o ciclo de avaliação e mudança é constante como em toda startup, como o entrevistado considera que a Vivenda seja. Ele também informou sobre situações que geraram necessidades de mudança e amadurecimento. A primeira delas foi a demanda de pessoas que gostariam e tinham dinheiro para reformar a casa toda e não apenas cômodos, como o negócio oferece tradicionalmente. Porém, a parcela ficava muito cara, porque há um limite de vezes em que os clientes podem pagar. Isso gerou a necessidade de 
criar novos mecanismos financeiros de parcelamento. Essa estratégia pode gerar uma priorização dos esforços da equipe em busca por ganhos financeiros em detrimento da missão social voltada para as pessoas de baixa renda e maior vulnerabilidade (GONIN et al., 2013)

Um aprendizado que aconteceu ao longo dos primeiros meses de atuação foi a descoberta de que nem todos os moradores que têm recursos financeiros para saírem da comunidade de baixa renda em que vivem querem fazer isso, porque sua rede de contatos sociais e o negócio que gerem estão lá. Esta aprendizagem ajudou a conhecer melhor o público-alvo, porém, não se concretizou em mudança ou aprimoramento na gestão.

Quando algo dá errado, há um esforço focado em consertar o problema, o que não pareceu ser um desgaste muito grande, talvez porque a participação de atores externos na gestão seja pequena, o que não é suficiente para gerar cobranças.

Por último, o entrevistado comentou que como os dados são todos da operação, não há dificuldade em coletá-los: “As vendas são feitas aqui, [...] se a gente não controlar quanto a gente está vendendo ou o orçamento previsto e realizado numa obra, a gente tá pisando no tomate no nosso quintal. Então, a gente não tem muita dificuldade. É o mínimo que nós temos que fazer."

\subsubsection{Comparação entre negócios sociais}

Entre os seis negócios pesquisados, a metade é da área de saúde (CIES, GlicOnline e Tem), um da indústria têxtil (PanoSocial), um de gestão de resíduos (Triciclos) e um de moradia (Vivenda). Nos casos da PanoSocial e Triciclos, a base da pirâmide é beneficiada com inclusão na cadeia de produção e nos outros quatro casos, como cliente final de acordo com a classificação de Yunus e Weber (2007).

Quanto à maior parte da população atendida pertencer à base da pirâmide de renda, como proposto por Acumen, os negócios acreditam que isso seja uma realidade, pela localização do negócio ou características do produto ou serviço ofertado, mas não há uma preocupação em investigar esse dado especialmente no caso dos serviços, que podem ser usados por qualquer pessoa. Metade dos negócios pesquisados beneficia algum público em específico, ou seja, atuam com foco: pessoas com diabetes, ex-detentos e catadores de materiais recicláveis.

Quanto à sustentabilidade financeira, metade das organizações já havia atingido seu ponto de equilíbrio financeiro, pelo menos em parte de sua operação. As demais desejavam e se planejavam para alcançar esse momento. Entre as que já conseguiam atuar sem investimento externo, algumas se interessaram por novas rodadas desse tipo de investimento 
para crescerem. Esse achado corrobora com o encontrado por Pipe (2017) em uma pesquisa com 579 negócios.

Para terem acesso aos investimentos externos, os negócios passaram por algum tipo de avaliação do fundo que investiu. A formalidade dessas avaliações variou entre o grupo. Há casos em que algumas conversas foram o suficiente, até outros casos em que foi exigida uma certificação externa, o GIIRS. Em muitas situações, as avaliações foram internas com métodos já testados pelo respectivo fundo.

O momento de formação do ecossistema de negócios sociais em que o Brasil se encontra talvez explique essa investigação menos profunda que precede o vínculo formal de empréstimo ou investimento. Como há uma grande dificuldade de avaliação social pela maior parte dos entrevistados, os ganhos de uma avaliação mais robusta talvez não justifiquem o esforço para alcançá-la, especialmente no momento de negociação. Para suprir a necessidade de conhecimento sobre o negócio a ser investido, os fundos são bastante atentos à equipe do negócio e como ela se propõe a resolver o problema social identificado.

Todos os negócios sociais pesquisados avaliavam ou já planejavam avaliar sua atuação. A avaliação dos aspectos operacionais e financeiros eram as mais desenvolvidas, o que está de acordo com a literatura encontrada, em que esses aspectos eram estudados há mais tempo. A Triciclos já avalia aspectos sociais por meio de dois métodos externos, GIIRS e Certificação B. CIES, PanoSocial e Tem estavam em diferentes fases de planejamento e implementação de avaliações com foco sociais, que já produziram reflexões internas nas equipes. GlicOnline e Vivenda ainda não começaram a planejar como seriam essas atividades internamente. Apenas a Triciclos e Vivenda usavam método externo para avaliação. Os demais usavam métodos internos, porém, com indicadores tradicionais como fluxo de caixa e número de usuários, o que vai de encontro a Oliveira Filho et al.(2013) que destacam a necessidade de adaptação dos métodos tradicionais para uso nos negócios sociais. No CIES, GlicOnline, PanoSocial e Tem, os investidores participaram da implementação da avaliação.

A maior parte dos negócios enxergava lições aprendidas com a análise dos resultados das avaliações, o que costuma gerar planos de ação e mudança. Algumas lições aprendidas na implementação das avaliações foram a forma de contagem dos usuários de um serviço e a importância da participação de diversas pessoas da equipe no processo de avaliação. A partir dos resultados das avaliações já foram aprendidas lições sobre o público beneficiado e foram alterados processos de atendimento e de testes, por exemplo. PanoSocial e Vivenda não reportaram lições aprendidas com a avaliação. A primeira ainda não considerava que avaliou propriamente seu desempenho e espera ter mais experiência de atuação para fazer isso com 
mais propriedade. A segunda enxergava diversos ciclos de aprendizagem e mudança, mas não necessariamente ligados à avaliação.

O aprimoramento dos processos em alguns desses seis negócios foi resultado da experiência do dia a dia, da observação, de erros que geraram reflexão, de ideias novas de funcionários e clientes e de um processo de tentativas e erros. A avaliação não foi o único indutor de aprendizagem e mudança que aconteceram por diversos outros motivos, porém, ela foi valorizada pelos entrevistados, eles afirmaram, na maior parte dos casos, que as melhorias que podem surgir das avaliações compensam seus custos.

As dificuldades em avaliar são identificadas, principalmente, para os indicadores sociais. Alguns obstáculos relatados para a aprendizagem foram as dificuldades de: isolar a atuação do negócio frente às outras ações para o mesmo público e coletar dados com órgãos públicos que não têm funcionários suficiente para isso (CIES), comparar o antes e o depois de uma intervenção social (GlicOnline), desenvolver um sistema eficiente para coleta e análise dos dados (Tem), conscientizar a equipe sobre a importância da avaliação e motivá-la a refletir sobre o andamento dos procedimentos constantemente (Triciclos) e, no âmbito operacional, isolar o custo dos produtos vendidos (PanoSocial). Apenas a Vivenda não percebia dificuldades em avaliar, porque considera que tem bastante proximidade e controle dos dados que coleta atualmente, os quais são operacionais e financeiros.

Quanto a como lidam com erros, o CIES relatou que havia uma grande pressão para que eles não ocorressem, talvez porque prestassem serviços e contas para o governo municipal de São Paulo que têm algumas fiscalizações. GlicOnline e PanoSocial enxergavam que alguns erros podiam comprometer toda a estrutura do negócio, mas não sentiam pressão de atores externos para evitá-los. Tem e Triciclos dificilmente não alcançavam metas propostas, a Tem informou que já sabia elaborar metas com grande potencial de alcance. Os erros foram associados à aprendizagem apenas pela PanoSocial.

O quadro a seguir relaciona os objetivos específicos, as categorias analisadas e alguns exemplos de conteúdo das respostas encontradas na pesquisa em relação aos negócios sociais. 
Quadro 5- Objetivos, categorias e resultados encontrados

\begin{tabular}{|c|c|c|}
\hline Objetivos & Categorias & Síntese dos resultados encontrados \\
\hline \multirow{5}{*}{$\begin{array}{l}\text { Caracterizar o negócio } \\
\text { social que faz avaliação }\end{array}$} & $\begin{array}{l}\text { Caracterização e missão da } \\
\text { organização (setor de atuação) }\end{array}$ & $\begin{array}{l}\text { Área de saúde, indústria têxtil, gestão de resíduos } \\
\text { e moradia. }\end{array}$ \\
\hline & Sustentabilidade financeira & $\begin{array}{l}\text { Alguns negócios já alcançaram a sustentabilidade } \\
\text { financeira, os demais se planejavam para isso. } \\
\text { Mesmo assim, pretendem se relacionar } \\
\text { novamente com investidores para crescerem. }\end{array}$ \\
\hline & Público atendido & $\begin{array}{l}\text { Pessoas de baixa renda (base da pirâmide), ex- } \\
\text { detentos e cooperativas de catadores de resíduos } \\
\text { sólidos. }\end{array}$ \\
\hline & Benefícios para a base da pirâmide & $\begin{array}{l}\text { Acesso à saúde e moradia e inclusão na cadeia } \\
\text { produtiva }\end{array}$ \\
\hline & $\begin{array}{l}\text { Participação do investidor na gestão } \\
\text { do negócio }\end{array}$ & $\begin{array}{l}\text { Varia de acordo com os casos. Os que mais } \\
\text { participam da gestão são os que mais avaliam. }\end{array}$ \\
\hline \multirow{6}{*}{$\begin{array}{l}\text { Caracterizar processos } \\
\text { avaliação nos negócios } \\
\text { sociais }\end{array}$} & Método de avaliação & $\begin{array}{l}\text { Método interno (sem o uso de certificação } \\
\text { externa), aspectos principais: financeiro e } \\
\text { operacional. }\end{array}$ \\
\hline & Como são analisados os dados & $\begin{array}{l}\text { Varia de reuniões de conselho com participação } \\
\text { dos investidores a uma maneira informal no } \\
\text { cotidiano da empresa. }\end{array}$ \\
\hline & $\begin{array}{l}\text { Envolvimento do investidor na } \\
\text { avaliação }\end{array}$ & $\begin{array}{l}\text { Foco do envolvimento está no planejamento e } \\
\text { implementação. }\end{array}$ \\
\hline & Motivação para avaliar & $\begin{array}{l}\text { Apresentar resultados para o fundo ou cliente, } \\
\text { melhorar a gestão. }\end{array}$ \\
\hline & Requisitos para investimento & $\begin{array}{l}\text { Alguma forma de avaliação que varia de } \\
\text { conversas com o investidor a uma avaliação pelo } \\
\text { GIIRS. }\end{array}$ \\
\hline & Como são aprimorados os processos & $\begin{array}{l}\text { Experiência do dia a dia, de erros que geraram } \\
\text { reflexão, de ideias novas de funcionários e } \\
\text { clientes e de um processo de tentativas e erros. }\end{array}$ \\
\hline \multirow{4}{*}{$\begin{array}{l}\text { Identificar e caracterizar } \\
\text { se os processos de } \\
\text { avaliação geram } \\
\text { aprendizagem na } \\
\text { organização na forma } \\
\text { lições aprendidas }\end{array}$} & $\begin{array}{l}\text { Lições aprendidas na } \\
\text { implementação da avaliação }\end{array}$ & $\begin{array}{l}\text { Importância da participação de diversas pessoas } \\
\text { da equipe no processo de avaliação. }\end{array}$ \\
\hline & $\begin{array}{l}\text { Lições aprendidas com os } \\
\text { resultados da avaliação }\end{array}$ & $\begin{array}{l}\text { Lições geraram alterações de processos de } \\
\text { atendimento e de testes. }\end{array}$ \\
\hline & Outros aprendizados & $\begin{array}{l}\text { Como os clientes se comportam em relação a uso } \\
\text { de consultas de especialidades médicas e como } \\
\text { moram. }\end{array}$ \\
\hline & Mudanças no comportamento & $\begin{array}{l}\text { Aprimoramento da rotina de testes de um } \\
\text { aplicativo, os horários de um exame médico para } \\
\text { um momento em que o médico está mais atento. }\end{array}$ \\
\hline \multirow[t]{2}{*}{$\begin{array}{l}\text { Identificar se existem } \\
\text { barreiras ou dificuldades } \\
\text { para os processos de } \\
\text { avaliação }\end{array}$} & Desafios de avaliação & $\begin{array}{l}\text { Isolar a atuação do negócio frente a outras ações } \\
\text { sociais, coleta de dados, desenvolvimento de } \\
\text { sistema para coleta e análise de dados, motivar a } \\
\text { equipe para importância da avaliação constante e } \\
\text { isolar o custo de cada recurso nos produtos } \\
\text { vendidos. }\end{array}$ \\
\hline & Custos de avaliar & $\begin{array}{l}\text { Tempo e esforço das equipes. Propriedade de uso } \\
\text { de algumas metodologias. }\end{array}$ \\
\hline
\end{tabular}

Fonte: dados da pesquisa 


\subsection{Organizações Avaliadoras}

As organizações avaliadoras não estavam no escopo inicial da pesquisa. Porém, por sugestão dos fundos de investimento e negócios sociais pesquisados e que se relacionam com essas organizações e pela pesquisadora julgar adequado, a Plano CDE e o Sistema B foram entrevistadas e também foram verificados documentos de avaliações feitos por ambas. A Plano CDE realizou uma avaliação qualitativa para a Vivenda para identificar os principais aspectos afetados com a melhoria na moradia. O Sistema B regula uma certificação obtida por Dín4mo, GAG, MOV, Vox e Triciclos.

\subsubsection{Descrição das Organizações}

\subsubsection{Plano CDE}

A Plano CDE é uma organização de pesquisa com foco na base da pirâmide. Seus serviços incluem pesquisa, inovação e impacto para clientes como empresas, organizações multilaterais, institutos, fundações, OSCs e negócios sociais.

A organização usa diversos métodos de avaliação de acordo com a necessidade do cliente. O mais complexo e caro é o "caso controle", em que uma população é avaliada em dois momentos distintos, antes e depois da intervenção social e comparada à outra população semelhante que não recebeu a intervenção e é avaliada nos mesmos dois momentos também. É necessário realizar quatro coletas de dados para esse tipo de avaliação.

Como avaliação da sua própria atuação, a Plano CDE usa a metodologia GIIRS, que o entrevistado considera uma ferramenta bastante completa, com indicadores de diversos aspectos. Além disso, há uma meta de quantos projetos devem ser feitos pela Plano CDE para organizações sociais e para empresas, o que requer uma avaliação. O entrevistado não enxerga lições aprendidas na implementação dessa avaliação interna e acredita que o esforço de aprimoramento dessa avaliação seria custoso demais para os ganhos resultantes do processo. Ele também não identifica lições aprendidas com os resultados da avaliação que faz internamente sobre a própria Plano $\mathrm{CDE}$, seu interesse se restringe ao monitoramento.

Os processos são aprimorados por meio de acompanhamento e avaliações informais. Nesse aspecto, enxerga-se uma contradição na fala do entrevistado, pois uma vez que houve aprimoramento, ocorreu o aprendizado de que algo poderia ser melhor. Ele também reconheceu lições aprendidas. Por exemplo, a Plano CDE constatou que os projetos para 
negócios sociais geravam $10 \%$ do valor financeiro que os projetos para grandes organizações do terceiro setor geram. Por isso, decidiram focar nas organizações de terceiro setor.

A Plano CDE acompanhava dentre o todo de projetos de pesquisa de impacto que a equipe fazia, qual parte era de projetos no geral (sem foco social) e qual parte era de projetos sociais, e há uma meta. Porém, quando a meta não era atendida, o entrevistado não enxergava muito espaço para manipulação da demanda de clientes. A Plano CDE não poderia rejeitar novas propostas que gerassem recursos financeiros na condição em que a Plano CDE se encontrava. O que faziam era voltar a comunicação e a divulgação para o terceiro setor e não para marcas que vendem para as classes C, D e E.

Ainda de acordo com o entrevistado, os negócios querem avaliar o impacto e em alguns casos são cobrados por isso, mas os negócios não sabem alguns dados diretos e básicos, como a demografia da população atendida. Muitas organizações não sabem qual porcentagem dos clientes pertence à base da pirâmide, porque não sabe sua renda, como também foi encontrado nessa pesquisa no caso dos negócios sociais.

\subsubsection{Sistema B}

O Sistema B é uma organização sem fins lucrativos que fomenta o ambiente e certifica as empresas B, que são empresas comprometidas institucionalmente em tomar decisões que considerem as consequências de suas ações em longo prazo na comunidade e meio ambiente em que atuam, utilizando a força de mercado para resolver problemas sociais e ambientais (SISTEMA B, 2017).

A entrevistada ressalta que "o Sistema B tem uma atuação não só na certificação e nas empresas, mas no ecossistema que dá base pra que essas empresas possam existir, que ele (o ecossistema) comece a mudar, o que a gente fala de mudar a regra do jogo.” O Sistema B atua também na parte de legislação própria para empresas desse tipo, parcerias com a academia e com outros programas para engajamento de pessoas para a causa, como premiações de moda, festivais e eventos. Os setores que mais possuem empresas B certificadas no Brasil são os serviços de consultoria e de meio ambiente, especialmente de gestão de resíduos, como a Triciclos, um dos casos selecionados.

O processo de certificação começa com o preenchimento de uma avaliação gratuita disponível no site da organização sobre governança, trabalhadores, comunidade e meio ambiente em que é possível alcançar de zero a 200 pontos. Se a empresa alcançar pelo menos 80 pontos, qualifica-se para seguir para a próxima fase, em que ela preenche uma avaliação robusta sobre o modelo de negócio. Após isso, há algumas ligações telefônicas de verificação 
e uma análise de documentos é feita pela equipe de certificação que fica nos EUA. Depois que tudo está adequado, é feita uma alteração no estatuto social da empresa que mostra o seu compromisso com a sociedade ao ser uma empresa B.

A entrevistada comentou que o interesse dos negócios em se certificarem parte da vontade de compreender e gerir melhor o impacto que elas geram, de ter uma certificação externa e de participar de um grupo que "tá fazendo diferente" (entrevistada Sistema B). Esse último motivo está de acordo com o que foi dito pelas empresas B pesquisadas.

A organização avalia sua atuação própria por meio do acompanhamento de quantas empresas estão em cada etapa da certificação. Essa avaliação gerou a lição aprendida de que as dificuldades das empresas no processo de certificação eram semelhantes mesmo se elas tivessem características diferentes, isso gerou implementação de workshops para grupos de empresas em processo de certificação, o que ajuda a ter mais empresas B certificadas rapidamente.

Quando acontecem erros ou metas não são atingidas, há reuniões para identificar falhas, aprendizados e rever as estratégias. A entrevistada reconhece que ainda há muito a aprimorar no processo de análise e reflexão sobre os dados, mas identifica um aprendizado constante enquanto a operação segue.

\subsubsection{Comparação das Organizações Avaliadoras}

Plano CDE e Sistema B se propõem a gerar valor para as organizações que compram seus serviços por meio de uma reflexão sobre sua atuação. O público da Plano CDE é diverso, enquanto do Sistema B são apenas empresas. Ao Sistema B interessa que um número cada vez maior de empresas se certifique, por isso, atua no ambiente para apoiar essa estratégia, já a Plano CDE não atua no ecossistema.

A Plano CDE usa uma metodologia personalizada para cada caso. Já a metodologia usada pelo Sistema B é a mesma independente do porte, localização ou setor de atuação da empresa, mas passa por mudanças a cada dois anos. Plano CDE avalia formalmente sua atuação, enquanto o Sistema B, uma organização bem recente, ainda está devolvendo esse processo. A maior parte dos aprendizados dessas organizações surgiu de reflexões sobre experiências que não a avaliação formal, dado que elas relatam muitos aprendizados e pouca avaliação formal. 


\section{ANÁlISE COMPARATIVA ENTRE TODAS AS ORGANIZAÇÕES POR CATEGORIAS ANALÍTICAS}

Neste tópico são analisados os dados em conjunto de fundos de investimento, negócios e organizações avaliadoras a partir das categorias de análise. A intenção é mostrar uma visão abrangente sobre como o ecossistema formado por negócios, investidores e avaliadores se encontra.

As categorias analíticas foram encontradas a partir dos roteiros de entrevista que, por sua vez, foram feitos a partir da revisão de literatura. As análises do começo deste tópico foram feitas por meio do software NVivo e serão abordadas na ordem dos objetivos específicos, ou seja, primeiro uma caracterização das organizações, depois as avaliações e formas de aprendizagem e por último, dificuldades em avaliar. Ao final, serão comentados outros achados de pesquisa além do escopo inicial.

Em relação à caracterização das organizações, chamou atenção o fato de seus discursos estarem mais próximos ao de empresas do que ao de organizações sociais tradicionais. Foi registrada a proximidade dos negócios sociais ao universo das startups que foram citadas em várias entrevistas. Referências às organizações da sociedade civil e ONGs raramente apareceram. O setor dos negócios sociais é também conhecido como "2.5", uma referência sobre o hibridismo de tais organizações que ficam entre o setor das empresas e o terceiro setor. Porém, esta pesquisa indica uma proximidade maior a um dos setores do que em a outro. A nuvem das 100 palavras mais ditas a partir de seis letras nas entrevistas mostra isso:

Figura 1- Nuvem de palavras mais ditas nas entrevistas

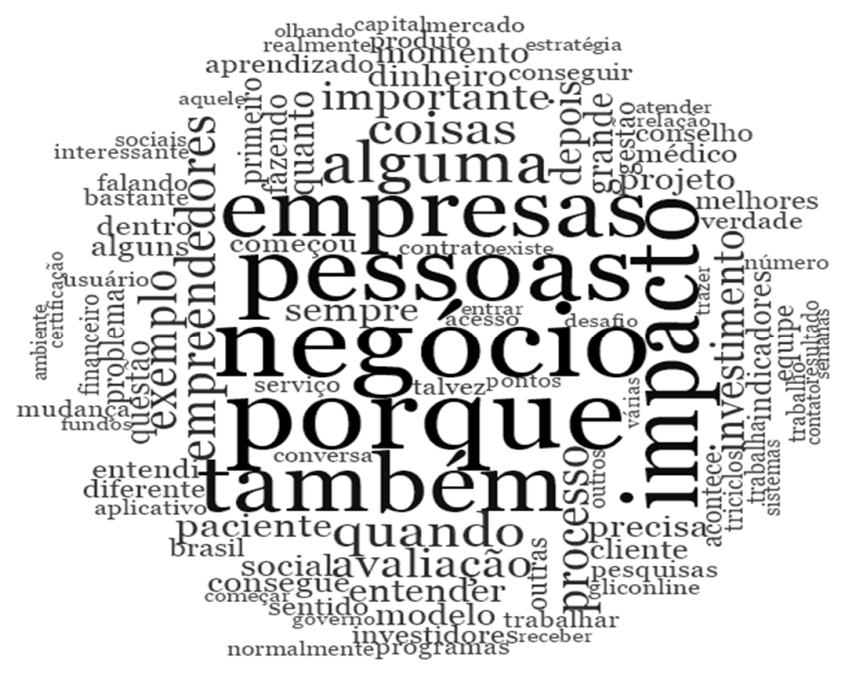

Fonte: dados da pesquisa a partir do softwareNVivo 
Nas organizações pesquisadas há algum tipo de avaliação ou monitoramento dos resultados, mesmo que ele ocorra de maneira bastante informal. Apesar de o termo "avaliação" não apresentar muito destaque na nuvem de palavras, esse tema foi o mais investigado e caracterizado. Isso gerou um grande número de referências nas entrevistas como mostra a tabela a seguir:

Quadro 6- Número de referências por categoria

\begin{tabular}{|c|c|c|}
\hline Objetivos específicos & Categorias de análise & Referências \\
\hline \multirow{7}{*}{$\begin{array}{l}\text { Caracterização da } \\
\text { organização }\end{array}$} & $\begin{array}{l}\text { Caracterização e missão da } \\
\text { organização (setor de atuação) }\end{array}$ & 13 \\
\hline & Sustentabilidade financeira & 13 \\
\hline & Público atendido & 17 \\
\hline & $\begin{array}{l}\text { Benefícios para a base da } \\
\text { pirâmide }\end{array}$ & 0 \\
\hline & Fundo investe ou empresta & 7 \\
\hline & $\begin{array}{l}\text { Participação do investidor na } \\
\text { gestão do negócio }\end{array}$ & 25 \\
\hline & Total & 75 \\
\hline \multirow{7}{*}{ Avaliação } & Método de avaliação & 50 \\
\hline & $\begin{array}{l}\text { Como são analis ados os } \\
\text { dados }\end{array}$ & 8 \\
\hline & $\begin{array}{l}\text { Envolvimento do investidor } \\
\text { na avaliação }\end{array}$ & 2 \\
\hline & Motivação para avaliar & 7 \\
\hline & $\begin{array}{l}\text { Requis itos para } \\
\text { inves time nto }\end{array}$ & 10 \\
\hline & $\begin{array}{l}\text { Como são aprimorados os } \\
\text { processos }\end{array}$ & 10 \\
\hline & Total & 87 \\
\hline \multirow{5}{*}{ Aprendizagem } & $\begin{array}{l}\text { Lições aprendidas na } \\
\text { implementação da avaliação }\end{array}$ & 18 \\
\hline & $\begin{array}{l}\text { Lições aprendidas com os } \\
\text { resultados da avaliação }\end{array}$ & 13 \\
\hline & Outros aprendizados & 12 \\
\hline & Mudanças no comportamento & 2 \\
\hline & Total & 45 \\
\hline \multirow{3}{*}{ Desafios da avaliação } & Desafios de avaliação & 12 \\
\hline & Custos de avaliar & 17 \\
\hline & Total & 29 \\
\hline \multirow{4}{*}{ Como lidam com erros } & Como lidam com erros & 17 \\
\hline & Atenção aos erros & 3 \\
\hline & Tolerância aos erros & 6 \\
\hline & Total & 26 \\
\hline
\end{tabular}

Fonte: dados da pesquisa a partir do softwareNVivo 
A forma como a avaliação é feita, o grau de complexidade e quem é o responsável por ela foram aspectos que variaram entre as organizações. Um aspecto que se destacou especialmente entre os negócios foi o uso de métodos tradicionais, como os usados por empresas comuns para avaliar os resultados, um exemplo é o fluxo de caixa. Apesar de haver um discurso de ineditismo e inovação sobre os negócios sociais, soluções tradicionais parecem resolver seus problemas. É provável que nos próximos anos, haja a exigência de análises mais robustas, profundas e que considerem as especificidades dos negócios sociais para que eles recebam investimento financeiro externo.

As avaliações geraram diversos tipos de aprendizados, tanto com a sua implementação quanto com os seus resultados. Há uma coincidência entre as organizações que aprenderam com a implementação e com os resultados. Apenas Dín4mo, MOV, PanoSocial e Vivenda não relataram lições aprendidas com a implementação e nem com os resultados. Apenas Bemtevi e as duas organizações avaliadoras (Plano CDE e Sistema B) não relataram lições aprendidas com os resultados.

É interessante notar que apesar do produto final das organizações avaliadoras serem análises sociais, elas mesmas não enxergam aprendizados com os resultados das avaliações feitas internamente. Além disso, nenhuma organização pesquisada de qualquer tipo aprende com os resultados se não tiver aprendido nada com a implementação da avaliação. Isso indica que se não houver o hábito de refletir durante o processo de avaliação, dificilmente ele será criado ao final. $\mathrm{O}$ quadro seguir mostra como as categorias lições aprendidas com implementação e com os resultados das avaliações se relacionam entre si e com as organizações estudadas:

Quadro 7- Relação entre lições aprendidas e organizações

\begin{tabular}{|c|c|c|c|}
\hline \multirow{2}{*}{$\begin{array}{l}\text { Organizações que não } \\
\text { relatam lições } \\
\text { aprendidas }\end{array}$} & \multicolumn{3}{|c|}{ Organizações que relatam lições aprendidas } \\
\hline & $\begin{array}{c}\text { Lições aprendidas } \\
\text { apenas com a } \\
\text { implementação } \\
\end{array}$ & $\begin{array}{c}\text { Lições aprendidas na } \\
\text { implementação e resultados } \\
\text { da avaliação }\end{array}$ & $\begin{array}{l}\text { Lições aprendidas } \\
\text { apenas com os } \\
\text { resultados da avaliação }\end{array}$ \\
\hline Dín4mo & Bemtevi & CIES & \multirow{7}{*}{ Não há } \\
\hline MOV & Sistema B & GAG & \\
\hline PanoSocial & \multirow{5}{*}{ Plano CDE } & GlicOnline & \\
\hline \multirow{4}{*}{ Vivenda } & & Sitawi & \\
\hline & & Tem & \\
\hline & & Triciclos & \\
\hline & & Vox & \\
\hline
\end{tabular}

Fonte: dados da pesquisa a partir do softwareNVivo 
Além das avaliações, as organizações aprendem de diversas outras formas. A avaliação foi uma indutora de aprendizagem, mas não foi a única. As organizações também aprendem por experiências do cotidiano, tentativas e erros, observação e de outras formas. Metade dos investidores (Bemtevi, Dín4mo e Vox Capital), ambos avaliadores (Plano CDE e Sistema B) e todos os negócios relatam aprendizados a partir de outras formas que não as avaliações formais. Em sua maioria, quando as organizações abordam esse assunto relatam mais de um aprendizado. É possível que isso se deva ao ambiente inovador e dinâmico, como retratado por alguns entrevistados em que os negócios sociais estão inseridos.

Quanto às dificuldades encontradas para avaliar, as maiores barreiras estão nas avaliações dos aspectos sociais. As principais dificuldades relatadas são referentes à multicausalidade e comparação entre o antes e o depois da intervenção. Esses aspectos são comuns às políticas públicas (DIAS e MATOS, 2012). Outra barreira identificada pelos entrevistados foi a não priorização da avaliação frente a outras atividades mais urgentes do dia a dia. Isso deve acontecer devido ao momento que o ecossistema vive, em que resultados sociais ainda não são exigidos como contrapartida a investimento externo.

Como sugerido por Marr (2006), outra dificuldade comum às avaliações são o momento de análise dos resultados, em que em alguns casos há uma busca por responsabilização pelos erros em vez de foco nas lições aprendidas e próximos passos. Baseado nisso, foi feita a pergunta de como as organizações lidam com erros e com o não atingimento de metas, o que não estava explicitamente descrito nos objetivos específicos, mas pode ser visto como um achado próximo às dificuldades de avaliar.

Comparando os três tipos de organizações, percebeu-se que a maior parte das falas sobre esse assunto foi feita pelos negócios sociais. Eles falam mais sobre uma necessidade de evitar erros a todo custo. Há indícios de que isso se deva ao fato de que metade dessas organizações são da área da saúde, em que erros na operação podem trazer consequências graves. Os negócios formulam metas alcançáveis e provavelmente menos desafiadoras, o que contrasta com a fala dos investidores sobre o mesmo tema, que atribuem aos erros oportunidades de inovação.

Por exemplo: "A (questão) da meta é complicada, porque o nosso, o financeiro tá atrelado à meta, então a gente atinge pontuações, então se a gente não atinge é complicado, porque a gente não tem o mesmo montante de financeiro, isso é bem complicado." (entrevistada do negócio social CIES) e "Faz parte do caráter inovador da organização, senão você não conseguiria inovar se você não pode testar e errar." (entrevistada SITAWI, que investe no CIES). Os fundos de investimentos parecem estar em uma posição em que erros de 
um negócio investido não causem grandes prejuízos para a organização como um todo. Os negócios parecem estar na posição contrária.

A partir daqui são apresentados outros comentários e percepções sobre a relação entre investidor e investido. Os resultados sistematizados pelo NVivo chamaram atenção para alguns desses achados, mas não foram a principal forma de análise utilizada.

Esta pesquisa teve um caráter qualitativo, o que prioriza profundidade em vez de abrangência, o conjunto de organizações pesquisado não funciona como uma amostra representativa do setor. Porém, chamou atenção a quantidade de negócios que se relacionam com investidor, o que também apareceu em um estudo quantitativo mais abrangente (PIPE, 2017). Dos fundos pesquisados, a maior parte investe em diversos negócios sociais, o que gera um questionamento sobre a real independência financeira desses negócios, como proposto por Yunus e Weber (2007), fato amplamente divulgado como uma vantagem dos negócios sociais sobre o modelo tradicional de organizações da sociedade civil.

MOV, Sitawi e Vox Capital comentaram que o processo de seleção de investimento se assemelha a um funil em que no início há centenas de negócios interessados e no final poucos recebem investimento. Por outro lado, percebeu-se que os negócios que estão maduros o suficiente para serem investidos ocupam uma posição privilegiada em que podem decidir ativamente com qual investidor preferem se relacionar o que fica claro pelo relato do CIES: "uma coisa que eu sei que conta muito pro doutor X (médico fundador do negócio) é o valor do outro parceiro. Se ele não se identifica, ou se ele acha que os valores não correspondem aos nossos do CIES, ele não alimenta tanto a parceria." E "se você não tá alinhado com uma pessoa da mesma forma de pensamento, pode ser contraditório pra sua própria ação" (entrevistada CIES). A Triciclos foi contatada pelo fundo, o que também mostra uma busca ativa dos fundos pelos negócios.

Apenas um negócio entrevistado comentou a tentativa de uma parceria com outro negócio que tem o investidor em comum. A tentativa não gerou o resultado esperado, mas há uma expectativa de tentar novamente quando um deles estiver mais maduro. 


\section{CONSIDERAÇÕES FINAIS}

Os negócios sociais são relevantes pelo grande número de pessoas que pretendem atingir por sua atuação. No entanto, eles são um fenômeno recente no Brasil e ainda pouco pesquisados por estudos acadêmicos (ROSOLEN et al, 2014). As áreas do conhecimento escolhidas para serem investigadas nesta pesquisa são também pouco estudadas, especialmente relacionadas uma à outra (avaliação e aprendizagem organizacional). Esse contexto ajudou a sugerir o seguinte objetivo de pesquisa: analisar se os negócios sociais utilizam práticas de avaliação e se isso gera processos de aprendizagem organizacional, tomando por base organizações que atuam no Estado de São Paulo.

Com o intuito de alcançar o objetivo proposto, foi realizada uma pesquisa qualitativa com três tipos de organizações do ecossistema (fundos de investimento, negócios sociais e organizações avaliadoras). Apesar de apenas os negócios sociais serem referidos no objetivo geral, os outros tipos de organização foram consultados por ajudarem a formar o contexto em que as avaliações e aprendizados acontecem.

A escolha das organizações se deu pelo estudo de uma publicação do setor que listava diversas organizações do ecossistema e, a partir daí, por indicação dos primeiros fundos entrevistados, em um esquema de bola de neve (GIL, 2009), de forma que as organizações se relacionavam entre si. Esse conjunto de organizações proporcionou, por suas características, uma análise de conteúdo por meio de categorias tiradas das referências bibliográficas sobre o tema.

Os resultados encontrados a partir daí, apresentam uma resposta positiva para o objetivo da pesquisa. Os negócios sociais utilizam práticas de avaliação e isso gera processos de aprendizagem organizacional na maior parte dos casos pesquisados. Porém a aprendizagem acontece muito além da avalição.

Quanto aos objetivos específicos, foram encontradas as seguintes respostas:

a) Caracterizar o negócio social que faz avaliação: os negócios sociais pesquisados vivem uma lógica mais próxima a das empresas do que das organizações sociais tradicionais;

b) Caracterizar e analisar processos avaliação nos negócios sociais: as avaliações ainda são caracterizadas pela informalidade e uso de métodos tradicionais, tais como análise do fluxo de caixa, análise do ciclo operacional, preço dos insumos a cada compra;

c) Identificar e caracterizar se os processos de avaliação geram aprendizagem organizacional na forma de lições aprendidas: as avaliações geram aprendizagem, mas não são a única forma de aprender algo novo, melhorar a gestão ou aprimorar os processos; 
d) Identificar e analisar se existem barreiras ou dificuldades para os processos de avaliação: há algumas barreiras, tais como dificuldades na coleta e análise de dados e falta de prioridade das atividades de avaliação.

É possível que a falta de atenção às avaliações ocorra porque elas não são vistas como a única forma de melhoria dos negócios sociais. Os negócios sociais ainda não se veem numa posição de necessidade de avaliar para aprender. É possível ainda que haja atividades de avaliação em grande ocorrência, mas que isso não seja reconhecido dado o caráter informal do processo. Pelos altos custos de avaliar formalmente, essa atividade é motivada por outros objetivos, como mostrar os resultados para investidores e clientes, e não para aprender.

Os casos estudados nessa pesquisa tendem a ser negócios sociais mais maduros que o geral, porque já são parceiros de um investidor, o que também é identificado por alguns atores do sistema: "Acho que o próprio ponto de você fazer o investimento, de você ter alguém de fora junto faz com que você busque constantemente o aprimoramento." (entrevistado MOV). No geral, a situação pode ser de avaliações ainda menos organizadas, se as organizações pesquisadas forem outliers.

Outras limitações da pesquisa identificadas foram a restrição geográfica e de área de atuação. Apesar de o planejamento inicial ser o Estado de São Paulo, apenas uma organização pesquisada estava fora do município de São Paulo, porém, entre as organizações contatadas, que foram mais de vinte, poucas estavam fora da capital. Em relação à área de atuação, metade das organizações sociais pesquisadas era da saúde, o que não é o mais representativo do setor, o qual conta com mais organizações na educação, de acordo com o levantamento de Aguiar e Naigeborin (2013). Pode ter acontecido uma má compreensão do termo avalição pelos respondentes, já que não houve um nivelamento sobre isso no momento da entrevista, essa seria outra limitação.

Considerando as limitações e os resultados desta pesquisa, depois desse esforço qualitativo para analisar o contexto em que o campo de negócios sociais se encontra no que tange a avaliação e aprendizagem, sugerem-se pesquisas quantitativas com uma abrangência maior, talvez nacional, sobre os mesmos assuntos e ecossistema.

A hipótese de que a avaliação leva a aprendizagem não se confirmou em quatro organizações das quatorze pesquisadas (Dín4mo, MOV, PanoSocial e Vivenda) de acordo com a percepção dos entrevistados. Até nos casos em que se confirmou, a ligação não é tão forte. Outra sugestão de pesquisa seria uma de caráter qualitativo que investigasse porque essas avaliações não geram todo o aprendizado que poderiam e o que precisaria mudar para que isso acontecesse. Uma pesquisa que identificasse quais são os principais indutores de 
aprendizagem nos negócios sociais ou que reforçasse esse caráter a partir da avaliação seria de grande valor para o campo empírico, que ainda precisa conhecer e se adequar muito ao público que pretende alcançar.

A contribuição teórica dessa pesquisa é uma maior compreensão dos fenômenos de avaliação e aprendizagem nos negócios sociais. A contribuição empírica consiste na indicação de que talvez seja necessário desenvolver o campo em outros aspectos até ele estar maduro o suficiente para executar e tirar benefícios de avaliações. A contribuição de ensino é o questionamento da avaliação como premissa para aprendizagem e melhorias organizacionais. 


\section{REFERÊNCIAS}

ABBAD, G. S.; BORGES-ANDRADE, J. E. Aprendizagem humana em organizações de trabalho. In: ZANELLI, J.C.; BORGES-ANDRADE, J. E.; BASTOS, A.V. Psicologia, organizações e trabalho no Brasil. 2a ed. Porto Alegre: Artmed, 2014.

ACUMEN.Social Impact. Disponível em: $<$ http://acumen.org/investments/investmentmodel/>. Acesso em: 19 out. 2014.

ACUMEN. (2017). What we do. Acesso em 17 de Jul. de 2017, disponível em http://acumen.org/about/

AGNIHOTRI, A. Doing Good and Doing Business at the Bottom of the Pyramid. Business Horizons, Indiana, v. 56, n. 5, p. 591-599, 1993.

AGUIAR, L.; NAIGABORIN, V. Mapeamento dos negócios com impacto social no Brasil. In: BARKI, E.Negócios com impacto social no Brasil. São Paulo: Peirópolis, 2013. p. 236249.

AlVeS-MAZZOTti, A. J. Usos e abusos dos estudos de caso. Cadernos de Pesquisa, São Paulo, v. 36, n.129, p. 637-651,set./dez. 2006.

AMORIM, W. A.; FISCHER, A. L. Aprendizagem organizacional: Uma análise sobre o debate e a escolha de categorias para estudos de caso. Perspectivas Contemporâneas, Paraná, v. 4, n. 1, p. 101-125, jan./jun. 2009.

AMORIM, W. A.; FISCHER, A. L. A aprendizagem organizacional e suas bases econômicas. Nova Economia, Minas Gerais, v. 23, n.2, p. 329-365. mai./ago. 2013.

ANTONELLO, C. S. A metamorfose da aprendizagem organizacional: uma revisão crítica. In: RUAS, R.; ANTONELLO, C. S.; BOFF, L. H.Aprendizagem organizacional e competências.Porto Alegre: Artmed, 2005. p. 12-33.

ARIZONA-MONTES, J. A.; MUNIZ, N. M. Virtual Ecosystems in Social Business Incubation. Journal of Electronic Commerce in Organizations, Queensland,v. 3, n.11, p. $27-45$, jul./set. 2013.

ARNOLD, D. G.; VALENTIN, A. Corporate Social Responsibility at the Base of the Pyramid. Journal of Business Research, v. 66, 1904-1914, 2013.

BARDIN, L. Análise de conteúdo. São Paulo: Edições 70, 2011.

BARKI, E.; COMINI, G.; CUNLIFFE, A., HART, S. L.; SUDHANSHU, R. Social Entrepreneurship and Social Bunisses: retrospective and prospective research. Revista de Administração de Empresas, São Paulo,v. 55, n. 4, p. 380-384, jul./ago. 2015.

BATTILANA, J., LEE, M., WLAKER J., DORSEY, C. (2012). In Search of the Hybrid Ideal. Stanford Social Innovation review. 
BATTISTELlA, C.; COLUCCI, K.; DE TONI, A. F.; NONINO, F. Methodology of Business Ecosystems Network Analysis: A case study in Telecom Italia Future Centre. Technological Forecasting \& Social Change, v.80, n. 6, p. 1194-1210, 2013.

BIGNETTI, L. P. As inovações sociais: uma incursão por ideias, tendências e focos de pesquisa. Ciências Sociais Unisinos, São Leopoldo, RS, v. 47, n.1, p. 3-14, jan./abr. 2011.

BURREL, G.; MORGAN, G. Sociological Paradigms and Organisational Analysis. Burlington: Ashgale Publishing Company, 2013.

CHAROUX, O. F. Metodologia: processo de produção, registro e relato do conhecimento. São Paulo: DVS Editora, 2006.

COMINI, G.; BARKI, E.; AGUIAR, L. T. A three-pronged approach to social business: a Brazilian multi-case analysis. Rev. Adm., São Paulo,v. 47, p. 385-397. jul./set. 2012.

CYERT, R.; MARCH, G. A. A Behavioral Theory of the Firm.Englewood Cliffs: Prentice Hall, 1963.

DIAS, R.; MATOS, F. Políticas públicas:princípios, propósitos e processo. São Paulo: Atlas, 2012.

EASTERBY-SMITH, M.; BURGOYNE, J.; ARAUJO, L. Aprendizagem Organizacional: desenvolvimento na teoria e na prática. São Paulo: Atlas, 2001

EASTERBY-SMITH, M.; THORPE, R.; LOWE, A. Management Research: An Introduction. Londres: Sage Publications, 1991.

FIOL, C. M.; LYLES, M. A. Organizational Learning. Academy of Management Review, New York, v. 4, n.10, p 803-813, 1985.

FISCHER, R. M. Negócios Sociais. In: OULLOSA, R. F. (Ed.).Dicionário para a formação em gestão social. Salvador: CIAGS/UFBA, 2014. p. 125-127.

FISCHER, R. M.; COMINI, G. Sustainable Development: from responsibility to entrepreneurship. R. Adm., São Paulo,v. 47, n.3, p. 363-369, jul./set. 2012.

FRANCO-SANTOS, M., KENNERLEY, M., MICHELI, P., MARTINEZ, V., MASON, S., MARR, B., GRAY, D., NEELY, A. Towards a definition of a business performance measurement system. In International Journal of Operations \& Production Management, Vol. 27 Issue: 8, pp.784-801 (2007)

FREEMAN, R. E. Strategic management: a stakeholder approach. Massachusetts: Pitman, 1984.

GIL, A. C. Estudo de Casos: Fundamentação científica, subsídios para coleta e análise de dados e como redigir o relatório. São Paulo: Atlas, 2009. 
GONIN, M.; BESHAROV, M.; SMITH, W.; GACHET, N. Managing social-business tensions: A review and research agenda for social enterprise. Business Ethics Quarterly, Cambridge ,v. 2, n.3, p. 407-442, 2013.

IIZUKA, E.; VARELA, C. A.; LARROUDÉ, E. R. Social Busines Dilemmas in Brazil: Rede Asta Case. RAE, São Paulo,v. 55, n.4, p.385-396, jul./ago. 2015.

INSTITUTO QUINTESSA.Guia 2.5: Guia para o desenvolvimento de negócios de impacto. São Paulo: Instituto Quintessa, 2015.

J. P. MORGAN, J. P. Impact Investments: An emerging asset class. New York: Global Research, 2010.

KARNANI, A. The mirage of marketing to the bottom of the pyramid: How the private sector can help alleviate poverty. California Management Review, Berkeley,v. 4, n. 49, p. 90-111, 2010.

KNOWLES, M. S.; HOLTON, E. F.; SWANSON, R. The Adult Learner. Londres: Elsevier, 2005.

KOLB, D. A. Experimental learning: experience as the source of learning. New Jersey: Prentice-Hall, 1984.

KONKERO. Disponível em: < http://www.projetocies.com.br/quem-somos>. Acesso em: 23 mar. 2015.

KYAMA, R.; COMINI, G.; D’AMARIO, E. Criação de Negócios Sociais no Brasil: Um Estudo Exploratório. Artigo aceito para apresentação na XXXVIII Enanpad. Rio de Janeiro: Enanpad, 2014. Disponível em:

$<$ http://www.anpad.org.br/admin/pdf/2014_EnANPAD_ESO1074.pdf>. Acesso em: 05 ago. 2017.

LI, Y.; CHEN, H.; LIU, Y.; PENG, M. W. Managerial ties, organizational learning, and opportunity capture: A social capital perspective. Asia Pac J Manag, v. 31, p. 271-291, 2014.

MANKIW, N. G. Consumption. Macroeconomics. 7a ed. New York: Worth Publishers, 2010.

MARR, B. Strategic Performance Management. Londres: Elsevier, 2006.

MEYER, M. Finding performance: the new discipline in management. In: NEELY, A.Business performance measurement: unifying theories and integrating practice. $2 \mathrm{a}$ ed. Londres: Cambridge University Press, 2007. p 113-124.

MOORE, J. F. Predators and prey: A new ecology competition. Harvard Business Review, New York v. 71, n. 5, p. 75-86, mai./jun. 1993.

NEELY, A.; MILLS, B.; PLATTS, K.; RICHARDS, H.; GREGORY, M.; BOURNE, M. Performance measurement system design: developing and testing a process-based approach International. International Journal of Operations \& Production Management, v. 20, n. 10, p. 1119-1145, 2000. 
OLIVEIRA FILHO, G. R.; KIYAMA, R. S.; COMINI, G. Os Desafios de Mensurar o Impacto Social. In: BARKI, E.Negócios com Impacto Social no Brasil. São Paulo: Peirópolis, 2013. p. 211-235.

ORGANIZATION FOR ECONOMIC CO-OPERATION AND DEVELOPMENT (OECD 2006). The social enterprise sector and a conceptual framework. Disponível em: $<$ http://www.oecd.org/regional/leed/37753595.pdf>. Acesso em: 19 out. 2014.

PORTER, M.; KRAMER, R. Strategy \& Society: The Link Between Competitive Advantage and Corporate Social Responsibility. Harvard Business Review, New York, p. 1-16, dez. 2006.

PORTOCARRERO, F. B.; DELGADO, M. Negocios Inclusivos y generación de valor social. In: MÁRQUEZ, P.;REFICCO, E.; BERGER, G. Negocios inclusivos - Iniciativas de mercado con los pobres de Iberoamérica. Bogotá: Amaral Editores / BID, 2010. p.265-300.

POZZEBON, M.; PETRINI, M. C. Critérios para Condução e Avaliação de Pesquisas Qualitativas de Natureza Crítico-Interpretativa. In: TAKAHASHI, A. R. Pesquisa Qualitativa em Administração: fundamentos, métodos e usos no Brasil. São Paulo: Atlas, 2013. p.51-72.

PRAHALAD, C.; HART, S. The fortune at the bottom of the pyramid. Strategy + Business, New York, v. 1, n. 26, p. 1-14, 2002.

PRANGE, C. Aprendizagem Organizacional: Desesperada em Busca de Teorias? In: EASTERBY-SMITH, M.; BURGOYNE, J.; ARAUJO, L.Aprendizagem Organizacional: desenvolvimento na teoria e na prática. São Paulo: Atlas, 2001.

PROJECT MANAGENT INSTITUTE, INC. (PMI). Um Guia do Conjunto de Conhecimentos em Gerenciamento de Projetos (Guia PMBOK®). $5^{\text {a }}$ edição. Project Management Institute, Inc. Newtown Square, Pensilvânia, EUA, 2008.

PROJECT MANAGENT INSTITUTE, INC. (PMI). 2016. Acesso em 13 de junho de 2016, disponível em O que é o PMI < https://brasil.pmi.org/brazil/AboutUS/WhatisPMI.aspx>

PROJETO CIES. Aba “Quem somos”. Disponível em: <http://www.projetocies.com.br/quemsomos>. Acesso em: 23 mar. 2015.

ROSOLEN, T.; TISCOSKI, G. P.; COMINI, G. M.. Empreendedorismo Social e Negócios Sociais: Um Estudo Bibliométrico da Publicação Nacional e Internacional. RIGS, Salvador, v. 3, n.1, p. 85-105, jan./abr. 2014.

SCHUMPETER, J. A. Capitalismo, socialismo e democracia. São Paulo: Zahar Editores, 1984.

SEBRAE. Banco de ideias: exemplos de negócios sociais no Brasil. Disponível em: < http://www.sebrae.com.br/Sebrae/Portal\%20Sebrae/Anexos/Anexo_VI_Exemplos_de_Negoc ios_Sociais_no_Brasil.pdf>. Acesso em: 23 mar. 2015a. 
SEBRAE. Aba "Quem somos". Disponível em:

$<$ http://www.sebrae.com.br/sites/PortalSebrae/canais_adicionais/conheca_quemsomos>.

Acesso em: 21 abr. $2015 b$.

SEBRAE. O posicionamento do Sebrae sobre negócios sociais Disponível em:

$<$ http://www.sebrae.com.br/sites/PortalSebrae/sebraeaz/O-posicionamento-do-Sebrae-nosneg\%C3\%B3cios-sociais $>$. Acesso em: 21 abr. 2015c.

SECCHI, L. Políticas Públicas. São Paulo: Cengage Learning, 2010.

SELLTIZ, C.; JAHODA, M.; DEUTSCH, M.; COOK, S. W. Research Methods in Social

Relations. New York: Henry Holt and Company, 1959.

SILVA, M. R. Indicadores dos Negócios Sociais na Área de Saúde: estudos de caso.2013. São Paulo: Dissertação (Mestrado em Administração) - Faculdade de Economia, Administração e Contabilidade, Universidade de São Paulo, São Paulo, 2013.

SILVA, Z. P., RIBEIRO, M. C. S. A., BARATA, R. B., ALMEIDA M. F. (2011, Jan). Perfil sociodemográfico e padrão de utilização dos serviços de saúde do Sistema Único de Saúde (SUS), 2003- 2008. Ciênc. saúde coletiva (16) 9, 3807-3816.

TASHMAN, P.; MARANO, V. Dynamic Capabilities and Base of the Pyramid Business Strategies. Journal of Business Ethics, v. 89, p. 495-514, 2010.

TUAN, M. T. Measuring and/or Estimating Social Value Creation: Insights Into Eight Integrated Cost Approaches. Disponível em: Bill \& Melinda Gates Foundation-Impact Planning and Improvement $<$ https://docs.gatesfoundation.org/Documents/wwl-reportmeasuring-estimating-social-value-creation.pdf>. Acesso em: 18 out. 2014.

YIN, R. K. Estudo de Caso Planejamento e Métodos. 4a ed. Porto Alegre: Bookman, 2010.

YUNUS, M.; WEBER, K. Social Business: What It Is and What It Is Not. In: YUNUS, M.; WEBER, K. Creating a world without poverty:social business and the future of capitalism. New York: The Public Affairs Books, 2007.

YUNUS, M.; MOINGEON, B.; LEHMANN-ORTEGA, L. Building Social Business Models: Lessons from the Grameen Experience. Long Range Planning, v. 43, p. 308-325, 2010. 


\section{APÊNDICE 1 - ROTEIRO DE ENTREVISTAS PRELIMINARES (ACELERADORAS E INVESTIDORES)}

1. Qual é a principal fonte de renda da organização? Vocês recebem investimento de algum fundo? Se sim, eles influenciam na seleção de novos participantes?

2. Há um processo seletivo para que as organizações ou empreendedores interessados na consultoria de vocês possam recebê-la? Como ele é feito?

3. Há alguma avaliação qualitativa de impacto social dos negócios apoiados? Como ela é feita?

4. Após junho de 2016 devo começar a coleta de dados para a minha pesquisa. Vocês teriam interesse e disponibilidade em participar? Vocês poderiam indicar também um investidor importante, se houver, e um projeto que se relacionam com vocês para também participarem? 


\section{APÊNDICE 2 - ROTEIRO DE ANÁLISE DOCUMENTAL E ENTREVISTAS COM INVESTIDORES}

\section{Roteiro de Análise Documental}

1. Qual é a organização de investimento?

2. Qual é a missão?

3. Qual é o processo de investimento? Quais etapas ou requisitos o negócio precisa cumprir para se mostrar apto a receber investido?

4. Como é o processo de seleção dos negócios a serem investidos?

5. Quais são os principais negócios sociais investidos?

\section{Roteiro de entrevista}

1. Vocês utilizam um método formal para avaliação de sua atuação dos negócios? Qual?

2. Para que este método é usado?

3. O custo do processo é absorvido pelo investidor ou pelo negócio?

4. A avaliação tem sido implementada através de indicadores criados pela própria organização ou usa uma metodologia externa? No caso da metodologia externa, porque ela foi escolhida?

5. Qual seria um exemplo de um negócio social que avalia sua atuação? 


\section{APÊNDICE 3 - ROTEIRO DE ANÁLISE DOCUMENTAL ENTREVISTAS COM NEGÓCIOS SOCIAIS}

\section{Roteiro de Análise Documental}

1. Qual é o negócio?

2. Qual é o ramo de atuação?

3. Qual é a missão?

4. A maior parte do público atendido pertence à base da pirâmide?

5. Como a base da pirâmide é beneficiada?

6. Qual é o número de clientes?

7. O negócio consegue manter suas atividades sem investimentos externos? Se não, há um planejamento para isso?

8. O negócio se relaciona com investidores? Como? O que foi exigido para ter acesso ao investimento?

9. O negócio social utiliza um método formal para avaliação de sua atuação? Qual?

10. O método de avaliação foi desenvolvido pela própria empresa ou é externo? Se for externa, porque ela foi escolhida?

11. Quais aspectos do desempenho são avaliados? Há indicadores financeiros e não financeiros? Há exemplos de cada?

\section{Roteiro de entrevista}

1. Para que a avaliação é usada?

2. A iniciativa de formalizar a avaliação partiu do próprio negócio ou de algum fator externo?

3. Há um custo envolvido no processo? Como ele é gerido?

4. Há uma busca pela quantificação ou dados qualitativos também são tidos como relevantes?

5. Como você caracteriza a rotina na organização quanto a incentivos de aprendizagem? Há responsabilização por erros? Novas formas de fazer as mesmas atividades são incentivadas?

6. Há reuniões para avaliação de resultados? Como são?

7. Você acredita que houve alguma lição aprendida no processo de implementação análise dos resultados da avaliação? Quais? Como foi esse processo de reflexão? 
8. E no estudo dos resultados da avaliação, houve lições aprendidas? Quais? Como foi esse processo de reflexão?

9. Houve alguma mudança no comportamento de vocês a partir das avaliações?

10. Há dificuldades para coleta e análise dos dados da avaliação? Quais?

a. Como elas são superadas?

b. Qual seria uma solução ideal para superá-las? 